\title{
Chlorococcales (exceto Scenedesmaceae) de pesqueiros da Região Metropolitana de São Paulo, SP, Brasil: levantamento florístico ${ }^{1}$
}

\author{
Edna Ferreira Rosini², Célia Leite Sant'Anna ${ }^{3}$ e Andréa Tucci ${ }^{3,4}$
}

Recebido: 26.04.2010; aceito: 16.02 .2012

\begin{abstract}
Chlorococcales (except Scenedesmaceae) from fishing ponds in the Metropolitan Region of São Paulo, São Paulo State, Brazil: a floristic survey). Studies in fishing ponds have mainly focused on economic issues and environmental impacts, while studies on the flora of micro algae are rarely performed. Therefore, the objective of this study was to perform a survey of the Chlorococcales from ten fishing ponds located in the Metropolitan Region of São Paulo. We identified 38 taxa, distributed in eight families, 19 genera and four varieties that are not typical of the species. With the exception of Scenedesmaceae, Chlorellaceae and Coelastraceae had the greatest number of taxa, 10 and eight species respectively, while Micractiniaceae, Radiococcaceae and Treubariaceae had the lowest numbers of taxa and frequencies of occurrence. Dictyosphaerium pulchellum was the only species with $90 \%$ frequency of occurrence. Out of the 38 taxa identified, 19 had a frequency of occurrence between 30-55\%, indicating a greater distribution of these species among the studied fishing ponds, corroborating the information in the literature, which argue that the Chlorococcales, Chlorophyceae species are well distributed in different Brazilians aquatic systems. The Scenedesmaceae family will be addressed separately due to its high wealth of taxa.
\end{abstract}

Key words: biodiversity, Dictyosphaerium, taxonomic

RESUMO - (Chlorococcales (exceto Scenedesmaceae) de pesqueiros da Região Metropolitana de São Paulo, SP, Brasil: levantamento florístico). Estudos em pesqueiros ressaltam, principalmente, questões econômicas e de impactos ambientais, enquanto que, estudos sobre a flora de microalgas raramente são realizados. Assim, o objetivo deste estudo foi realizar o levantamento das Chlorococcales em dez pesqueiros da Região Metropolitana de São Paulo. Foram identificados 38 táxons, distribuídos em oito famílias, 19 gêneros e quatro variedades que não as típicas das espécies. Com exceção de Scenedesmaceae, Chlorellaceae e Coelastraceae apresentaram maior riqueza, 10 e oito espécies respectivamente, enquanto que, Micractiniaceae, Radiococcaceae e Treubariaceae apresentaram as menores riquezas e as menores frequências de ocorrência. Dictyosphaerium pulchellum foi a única espécie com $90 \%$ de frequência de ocorrência. Dos 38 táxons identificados, 19 apresentaram frequência de ocorrência entre 30-55\%, indicando melhor distribuição dessas espécies entre os pesqueiros estudados, corroborando com as informações da literatura, que discutem que várias espécies de Chlorococcales, Chlorophyceae são bem distribuídas entre os diferentes sistemas aquáticos brasileiros. A família Scenedesmaceae, pela elevada riqueza de táxons, será abordada separadamente.

Palavras-chave: biodiversidade, Dictyosphaerium, fitoplâncton, taxonomia

\section{Introdução}

Pesqueiro é um nome genérico atribuído aos "pesque-pague", "pague-pesque", "pesque e solte" e lagos da pesca esportiva ou recreativa (Gentil 2007). Essa atividade tem apresentado importante fonte de lazer e turismo principalmente próximo aos grandes centros urbanos (Esteves \& Sant'Anna 2006).
No entanto, a aquicultura pode ser responsável por alguns problemas ambientais, como: impactos aos sistemas naturais que recebem seus efluentes, escape acidental ou não de espécies exóticas, inserção de patógenos, uso de produtos orgânicos ou químicos, geração de resíduos e modificações decorrentes da instalação do empreendimento (Eler et al. 2006). Mas, um dos maiores problemas encontrados nos

1. Parte da dissertação de Mestrado do primeiro Autor. Programa de Pós-graduação em Biodiversidade e Meio Ambiente

2. Programa de Pós-graduação em Biodiversidade Vegetal e Meio Ambiente, Caixa Postal 68041, 04045-972 São Paulo, SP, Brasil

3. Instituto de Botânica, Núcleo de Pesquisa em Ficologia, Caixa Postal 68041, 04045-972 São Paulo, SP, Brasil

4. Autor para correspondência: atuccic@ig.com.br 
pesqueiros é, sem dúvida, a eutrofização artificial que, particularmente, nesses ambientes, é intensificada pelo constante arraçoamento e ceva (Mercante et al. 2006). A eutrofização em pesqueiros ou viveiros de piscicultura vem sendo registrada por Mercante et al. (2004, 2005, 2006, 2007) e Eler et al. (2006). Esse processo produz alterações na qualidade da água, como a redução do oxigênio dissolvido, o aumento de incidências de florações de microalgas e cianobactérias $\mathrm{e}$, frequentemente, a morte extensiva de peixes e perda da qualidade cênica (Mercante et al. 2005).

A preocupação com os possíveis impactos ambientais gerados por essa atividade fez com que alguns estudos relativos às questões ambientais e gerenciamento em pesqueiros fossem realizados no Estado (Kitamura et al. 1999, na bacia do rio Piracicaba; Lopes 2000, nas sub-bacias do Baixo Tietê, Turvo Grande e São José dos Dourados; Eler et al. 2006, na bacia do rio Mogi-Guaçu e Esteves \& Sant'Anna 2006, na bacia do Alto Tietê). Para a Região Metropolitana de São Paulo, Esteves \& Sant'Anna (2006) realizaram um estudo em trinta pesqueiros sob uma visão integrada de meio ambiente, saúde pública e manejo.

A taxonomia tem importância como base do conhecimento científico (Senna \& Magrin 1999), e atualmente a análise molecular tem sido a principal ferramenta usada para mudanças e elaboração de novos sistemas de classificações. O gene comumente empregado em análises moleculares tem sido a menor subunidade do RNA ribossômico, o gene $18 \mathrm{~S}$ nos eucariotos (Fawley et al. 2004). Dentre os trabalhos com abordagem polifásica e enfoque filogenético, relacionados à taxonomia de Chlorococcales, destacam-se An et al. (1999), Buchheim et al. (2005) e Hepperle et al. (2000), utilizados no presente estudo.

Estudos voltados para avaliação da composição taxonômica ou relacionados à estrutura e dinâmica da comunidade fitoplanctônica em pesqueiros da região metropolitana de São Paulo foram desenvolvidos por Matsuzaki et al. (2004), Silva (2005), Sant'Anna et al. (2006) e Gentil (2007).

Matsuzaki et al. (2004) realizaram um estudo qualitativo da comunidade fitoplanctônica de um pesqueiro localizado na Bacia do Guarapiranga e identificaram 91 táxons distribuídos em oito classes, sendo Chlorophyceae a classe com $52 \%$ dos táxons identificados. No entanto, não foram apresentadas descrições e/ou ilustrações dos táxons registrados.

A dinâmica de populações de Microcystis (Cyanobacteria) em 20 pesqueiros da região metropolitana de São Paulo foi avaliada por Silva (2005) que registrou, com descrições e ilustrações, quatro espécies: M. aeruginosa (Kützing) Kützing, M. protocystis Crow, M. wesenbergii (Komárek) Komárek e $M$. panniformis Komárek et al.; embora outras cianobactérias tenham sido registradas com elevadas densidades, como Aphanocapsa holsatica (Lemmermann) Cronberg \& Komárek, A. elachista W. West \& G.S.West e Merismopedia tenuissima Lemmermann.

Sant'Anna et al. (2006) e Gentil (2007) analisaram a estrutura da comunidade fitoplanctônica em 30 pesqueiros da Região Metropolitana de São Paulo. Sant'Anna et al. (2006) verificaram maior representatividade de clorofíceas e cianobactérias em termos de riqueza e abundância do fitoplâncton, respectivamente, e a relacionaram com o elevado grau de enriquecimento desses sistemas e com o manejo empregado. Gentil (2007) registrou 708 táxons em 30 pesqueiros, $48 \%$ de Chlorophyceae e por ser um estudo ecológico, ilustrou 15 táxons, oito destes, clorofíceas.

Chlorophyceae é a classe que se destaca, quanto à riqueza de táxons, dentre os organismos que compõem a comunidade fitoplanctônica, em vários ambientes de águas continentais brasileiras, com cerca de $50 \%$ do total de organismos encontrados. Exemplos desta porcentagem foram registrados por Sant'Anna et al. (1989, 1997, 2006), Beyruth et al. (1998), Bicudo et al. (1999), Beyruth (2000), Huszar et al. (2000), Carvalho (2003), Tucci et al. (2004, 2006), Ferragut et al. (2005), Gentil et al. (2008), Nogueira et al. (2008), Rodrigues (2008), Granado et al. (2009), em sistemas aquáticos com diferentes condições ambientais e graus de trofia, indicando que, de maneira geral, as Chlorophyceae estão amplamente distribuídas nas águas continentais brasileiras.

Assim, o presente estudo será o primeiro trabalho especificamente taxonômico relativo ao conhecimento da biodiversidade de Chlorococcales (com exceção da família Scenedesmaceae) planctônicas em pesqueiros da Região Metropolitana de São Paulo.

\section{Material e métodos}

Área de Estudo - Os dez pesqueiros estudados estão localizados na Bacia Hidrográfica do Alto Tietê, Região Metropolitana de São Paulo, e estão identificados pelos códigos numéricos: $8,9,10,11$, $14,16,18,25,27$ e 30 (figura 1). A bacia do Alto 


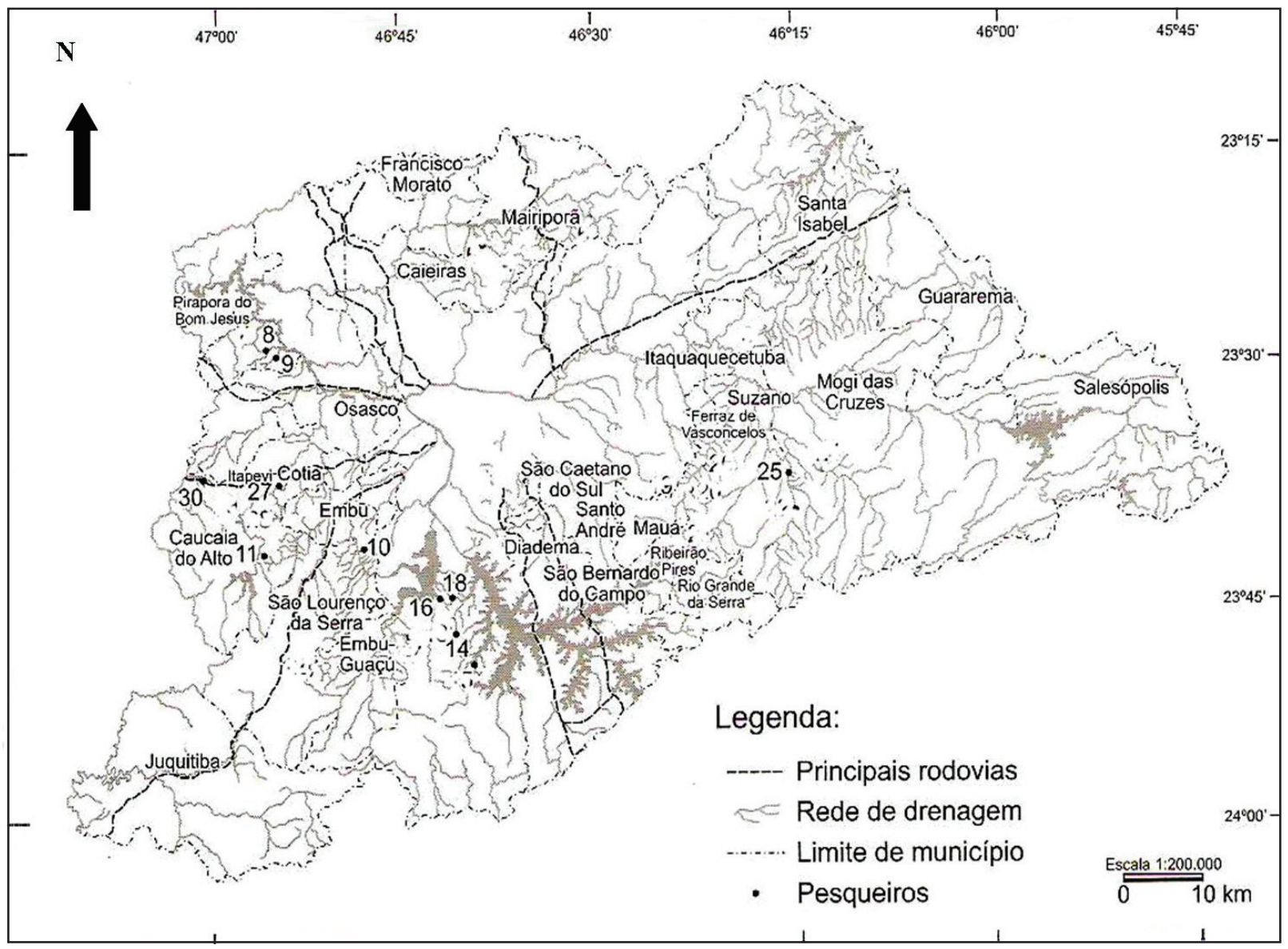

Figura 1.Localizaçãodos pesqueiros estudados na Região Metropolitana deSãoPaulo, SP, Brasil(RMSP)(modificado dePresotto \& Cabianca2006).

Figure 1. Location of the studied fishing ponds in the Metropolitan Region of São Paulo, São Paulo State, Brazil (RMSP) (modified Presotto \& Cabianca 2006).

Tietê corresponde desde a área drenada pelo rio Tietê à montante da Barragem de Pirapora até as suas nascentes em Salesópolis (35 municípios, a maioria deles integrantes da RMSP). Possui aproximadamente 37\% de área urbanizada (Esteves \& Sant'Anna 2006).

Os pesqueiros estão distribuídos em cinco sub-bacias: a) Sub-bacia do Rio Tietê Alto - Zona Metropolitana, onde estão localizados dois pesqueiros de código 8 e 9. b) Sub-bacia do Reservatório Billings, onde está localizado o pesqueiro de código 14 . c) Sub-bacia do Rio Tietê Alto-Cabeceiras, onde está localizado o pesqueiro de código 25. d) Sub-bacia do Rio Cotia, onde estão localizados os pesqueiros de código 11, 27 e 30. e) Sub-bacia do Reservatório Guarapiranga, onde estão localizados os pesqueiros de código 10, 16 e 18.

As amostras de água para o estudo taxonômico foram coletadas na sub-superfície da coluna d'água, filtradas com rede de plâncton, com abertura de malha de $20 \mu \mathrm{m}$ e preservadas em formol a $4-5 \%$. A profundidade média dos pesqueiros variou entre $1,0 \mathrm{e}$ $1,5 \mathrm{~m}$. As coletas foram realizadas próximas à região central de cada sistema em duas épocas: setembro/ outubro de 2001 (final do período de estiagem: seca) e fevereiro/março de 2002 (final do período chuvoso: chuva), totalizando 20 amostras $(n=20)$.

A identificação foi feita analisando-se as características morfológicas e métricas das populações de, no mínimo, 20 indivíduos de cada espécie. Indivíduos isolados somente foram identificados quando suas características diacríticas estiveram presentes e concordavam com a circunscrição específica do táxon que representava.

O exame das amostras foi realizado por meio de microscópio fotônico, Zeiss Axioplan 2, com câmara clara, retículo micrometrado e câmera fotográfica acoplados, em aumentos de 400 e 1.000 vezes. Foi utilizado contraste de fase e nanquim para evidenciar bainhamucilaginosaeiodo para evidenciargrãode amido.

As amostras estão depositadas no acervo do Herbário Científico do Estado "Maria Eneyda P. Kauffmann Fidalgo" (SP) do Instituto de Botânica, São Paulo, SP. 
A partir do registro dos táxons nas amostras $(\mathrm{n}=20)$, foi calculada a frequência de ocorrência $(\mathrm{F}=\%)$. As espécies com $\mathrm{F}$ entre $5-25 \%$ foram consideraras raras $(\mathrm{R})$; as espécies com $\mathrm{F}$ entre $30-55 \%$ foram consideradas comuns (C) e as espécies com $\mathrm{F}$ acima de $60 \%$ foram consideradas constantes (CS).
Os valores das variáveis físicas, químicas e biológicas da água dos pesqueiros, obtidos por Gentil (2007), estão na tabela 1.

Este estudo fez parte do projeto "Diagnóstico ecológico-sanitário de pesqueiros da Região Metropolitana de São Paulo" (Processo FAPESP n॰ 01/04081-8).

Tabela 1. Valores das variáveis físicas, químicas e biológicas da água nas épocas de seca e de chuva nos pesqueiros da Região Metropolitana de São Paulo, Brasil (P: código numérico do pesqueiro; S: seca; C: chuva; UA: unidade amostral; $\mathrm{T}^{\circ} \mathrm{C}$ : temperatura da água $\mathrm{em}^{\circ} \mathrm{C}$; Cond: condutividade em $\mu \mathrm{S} \mathrm{cm}^{-1} ; \mathrm{pH}$ : potencial hidrogeniônico; OD: oxigênio dissolvido em mg L ${ }^{-1}$; Tur: turbidez em NTU; Sec: transparência ao disco de Secchi em metros; Alc: alcalinidade; $\mathrm{NH}_{4}^{+}$: amônio em $\mu \mathrm{g} \mathrm{L}{ }^{-1} ; \mathrm{NO}_{2}$ : nifrito em $\mu \mathrm{g} \mathrm{L}^{-1} ; \mathrm{NO}_{3}^{-}$: nitrato em $\mu \mathrm{g} \mathrm{L}^{-1} ; \mathrm{P}^{-} \mathrm{PO}_{4}^{-}$: fósforo solúvel reativo em $\mu \mathrm{g} \mathrm{L}^{-1} ;$ PT: fósforo total em $\mu \mathrm{g} \mathrm{L}^{-1}$; Cl-a: clorofila-a em $\mu \mathrm{g} \mathrm{L}^{-1}$ ) (modificado de Gentil 2007).

Table 1. Values of the physical, chemical and biological variables of the water in the studied fishing ponds during drought and rainfall periods, in the Metropolitan Region of São Paulo, Brazil (P: code number of the fishing pond; S: drought; C: rain; UA: sampling unit; $\mathrm{T}^{\circ} \mathrm{C}$ : water temperature in ${ }^{\circ} \mathrm{C}$; Cond: conductivity in $\mu \mathrm{S} \mathrm{cm}^{-1}$; $\mathrm{pH}$ : hydrogen potential; OD: dissolved oxygen in $\mathrm{mg} \mathrm{L}^{-1}$; Tur: turbidity in NTU; Sec: Secchi disk transparency in meters; Alc: alkalinity; $\mathrm{NH}_{4}^{+}$: ammonium in

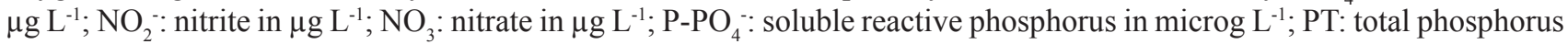
in microg $\mathrm{L}^{-1}$, Cl-a: chlorophyll-a in $\mu \mathrm{g} \mathrm{L}^{-1}$ ) (modified from Gentil 2007).

\begin{tabular}{lrrrrrrrrrrrrr}
\hline UA & $\mathrm{T}^{\circ} \mathrm{C}$ & Cond & $\mathrm{pH}$ & $\mathrm{OD}$ & $\mathrm{Tur}$ & $\mathrm{Sec}$ & $\mathrm{Alc}$ & $\mathrm{NH}_{4}^{+}$ & $\mathrm{NO}_{2}^{-}$ & $\mathrm{NO}_{3}^{-}$ & $\mathrm{PO}_{4}^{-}$ & $\mathrm{PT}$ & $\mathrm{Cl}-\mathrm{a}$ \\
\hline P8S & 19,9 & 89,6 & 7,1 & 6,6 & 23 & 0,4 & 56,7 & 230 & 8,7 & 75,2 & 10,0 & 86,0 & 30,9 \\
P8C & 24,2 & 100,0 & 6,1 & 4,4 & 34 & 0,5 & 50,5 & 230 & 6,6 & 58,7 & 4,4 & 82,4 & 19,2 \\
P9S & 21,7 & 56,2 & 7,2 & 10,3 & 11 & 0,5 & 31,5 & 260 & 11,5 & 80,4 & 9,6 & 93,5 & 11,9 \\
P9C & 25,1 & 70,0 & 5,9 & 6,1 & 26 & 0,5 & 37,9 & 310 & 7,8 & 63,9 & 5,4 & 82,4 & 22,0 \\
P10S & 18,5 & 203,0 & 7,3 & 6,0 & 37 & 0,3 & 71,4 & 900 & 5,3 & 96,3 & 32,4 & 170,1 & 43,9 \\
P10C & 25,3 & 470,0 & 6,8 & 7,0 & 55 & 0,2 & 94,7 & 270 & 2,4 & 80,2 & 12,5 & 349,7 & 103,4 \\
P11S & 19,7 & 31,4 & 8,5 & 10,6 & 19 & 0,6 & 10,5 & 660 & 7,5 & 77,8 & 8,5 & 116,6 & 27,5 \\
P11C & 25,2 & 60,0 & 5,6 & 7,9 & 17 & 0,8 & 18,9 & 200 & 4,8 & 69,7 & 3,8 & 81,1 & 14,5 \\
P14S & 24,7 & 125,0 & 7,6 & 8,5 & 15 & 0,5 & 56,7 & 860 & 7,8 & 69,4 & 9,3 & 176,4 & 51,0 \\
P14C & 25,4 & 130,0 & 6,1 & 6,1 & 30 & 0,3 & 54,7 & 220 & 5,1 & 56,2 & 2,9 & 183,3 & 58,6 \\
P16S & 22,5 & 27,1 & 6,6 & 7,9 & 60 & 0,2 & 12,6 & 770 & 11,6 & 183,1 & 26,4 & 120,1 & 113,0 \\
P16C & 28,0 & 50,0 & 6,3 & 8,3 & 86 & 0,2 & 16,8 & 390 & 6,1 & 21,9 & 7,7 & 168,6 & 134,6 \\
P18S & 22,5 & 32,0 & 6,9 & 11,0 & 11 & 0,4 & 16,8 & 160 & 4,2 & 0,0 & 10,1 & 57,2 & 25,4 \\
P18C & 29,0 & 60,0 & 7,6 & 14,6 & 42 & 0,4 & 25,3 & 220 & 4,0 & 88,5 & 10,1 & 31,1 & 43,2 \\
P25S & 22,8 & 260,0 & 6,8 & 5,2 & 44 & 0,3 & 94,6 & 460 & 4,2 & 18,9 & 10,4 & 124,4 & 69,5 \\
P25C & 27,6 & 160,0 & 6,2 & 5,2 & 47 & 0,4 & 52,6 & 166 & 7,7 & 14,7 & 5,9 & 76,7 & 33,6 \\
P27S & 22,5 & 230,0 & 6,6 & 8,3 & 26 & 0,4 & 62,4 & 380 & 7,7 & 69,9 & 7,6 & 120,2 & 51,3 \\
P27C & 29,2 & 200,0 & 6,2 & 6,1 & 41 & 0,3 & 48.4 & 360 & 3,0 & 55,0 & 8,0 & 141,6 & 46,7 \\
P30S & 23,2 & 170,0 & 8,1 & 12,4 & 44 & 0,3 & 68,8 & 360 & 9,2 & 69,9 & 6,7 & 283,9 & 125,9 \\
P30C & 28,3 & 130,0 & 8,1 & 13,6 & 65 & 0,3 & 44,2 & 330 & 7,9 & 49,1 & 6,2 & 225,5 & 430,2 \\
\hline
\end{tabular}

Resultados e Discussão

Dentre as espécies de Chlorococcales identificadas nos pesqueiros estudados, a família Scenedesmaceae foi a que apresentou o maior número de táxons (26) e os gêneros Scenedesmus e Desmodesmus destacaram-se por apresentar o maior número de espécies, além de grande polimorfismo, motivo pelo qual serão apresentados em um artigo separado (em preparação). Porém, além desses gêneros, outros dois destacaram-se pelo número de espécies encontradas, aqui apresentadas: Coelastrum e Kirchneriella, com seis e quatro espécies, respectivamente (tabela 2). As famílias que apresentaram as menores riquezas 
Tabela 2. Frequência de ocorrência dos táxons encontrados nos pesqueiros nos dois períodos de estudo, Região Metropolitana de São Paulo, Brasil (P: pesqueiros, C: chuva, S: seca, *: táxons exclusivos da época de chuva, em negrito valores máximos e mínimos da riqueza de táxons, R: rara, C: comuns e CS: constante).

Table 2. Frequency of occurrence of the taxa found in the fishing ponds in the two study periods, Metropolitan Region of São Paulo, Brazil (P: fishing pond, C: rain, S: dry, *: taxa exclusive of the rainy season, bold typed maximum and minimum taxa richness, R: rare $\mathrm{C}$ : common and CS: constant).

\begin{tabular}{|c|c|c|c|c|c|c|c|c|c|c|c|c|c|c|c|c|c|c|c|c|c|}
\hline \multirow{2}{*}{ Táxons } & \multicolumn{2}{|c|}{ P 8} & \multicolumn{2}{|c|}{ P9 } & \multicolumn{2}{|c|}{$\mathrm{P} 10$} & \multicolumn{2}{|c|}{ P11 } & \multicolumn{2}{|c|}{$\mathrm{P} 14$} & \multicolumn{2}{|c|}{ P16 } & \multicolumn{2}{|c|}{$\mathrm{P} 18$} & \multicolumn{2}{|c|}{$\mathrm{P} 25$} & \multicolumn{2}{|c|}{$\mathrm{P} 27$} & \multicolumn{2}{|c|}{$\mathrm{P} 30$} & \multirow[b]{2}{*}{$\mathrm{F} \%$} \\
\hline & $\mathrm{C}$ & $\mathrm{S}$ & $\mathrm{C}$ & $\mathrm{S}$ & $\mathrm{C}$ & $\mathrm{S}$ & $\mathrm{C}$ & $\mathrm{S}$ & $\mathrm{C}$ & $\mathrm{S}$ & $\mathrm{C}$ & $\mathrm{S}$ & $\mathrm{C}$ & $\mathrm{S}$ & $\mathrm{C}$ & $\mathrm{S}$ & $\mathrm{C}$ & $\mathrm{S}$ & $\mathrm{C}$ & $\mathrm{S}$ & \\
\hline Chlorophyceae / Chlorococcales & & & & & & & & & & & & & & & & & & & & & \\
\hline Botryococcaceae & & & & & & & & & & & & & & & & & & & & & \\
\hline 1 Botryococcus braunii & & & & $\mathrm{X}$ & & & & & $\mathrm{X}$ & & $\mathrm{X}$ & $\mathrm{X}$ & & & & & & & $\mathrm{X}$ & & $25 \mathrm{R}$ \\
\hline 2 B. terribilis & & & $\mathrm{X}$ & $\mathrm{X}$ & & $\mathrm{X}$ & & & & $\mathrm{X}$ & $\mathrm{X}$ & $\mathrm{X}$ & & & & & $\mathrm{X}$ & & & & $35 \mathrm{C}$ \\
\hline 3 Dictyosphaerium ehrenbergianum & & & & $\mathrm{X}$ & & $\mathrm{X}$ & $\mathrm{X}$ & & & & & & & $\mathrm{X}$ & $\mathrm{X}$ & $\mathrm{X}$ & $\mathrm{X}$ & & $\mathrm{X}$ & & $40 \mathrm{C}$ \\
\hline 4 D. pulchellum & $X$ & $X$ & $\mathrm{X}$ & $X$ & $X$ & $X$ & $X$ & $X$ & $X$ & $X$ & $X$ & & & $X$ & $\mathrm{X}$ & $\mathrm{X}$ & $X$ & $\mathrm{X}$ & $X$ & $\mathrm{X}$ & $90 \mathrm{CS}$ \\
\hline 5 D. tetrachotomum & & & & & $\mathrm{X}$ & & & $\mathrm{X}$ & $\mathrm{X}$ & & & & $\mathrm{X}$ & & $\mathrm{X}$ & $\mathrm{X}$ & & & $\mathrm{X}$ & & $35 \mathrm{C}$ \\
\hline sub total & 1 & 1 & 2 & 4 & 2 & 3 & 2 & 2 & 3 & 2 & 3 & 2 & 1 & 2 & 3 & 3 & 3 & 1 & 4 & 1 & \\
\hline Chlorellaceae & & & & & & & & & & & & & & & & & & & & & \\
\hline 1 Ankistrodesmus bibraianus & & & $\mathrm{X}$ & $\mathrm{X}$ & $\mathrm{X}$ & & $\mathrm{X}$ & & & & $\mathrm{X}$ & $\mathrm{X}$ & & $X$ & $\mathrm{X}$ & $\mathrm{X}$ & & & & & $45 \mathrm{C}$ \\
\hline 2 A. fusiformis & & & & & & & & & & & $\mathrm{X}$ & & & & & & & & & $\mathrm{X}$ & $10 \mathrm{R}$ \\
\hline 3 A. gracilis & & $\mathrm{X}$ & & & & & & & $\mathrm{X}$ & & & $\mathrm{X}$ & & & & & & & $\mathrm{X}$ & & $20 \mathrm{R}$ \\
\hline 4 Kirchneriella aperta & & $\mathrm{X}$ & & & $\mathrm{X}$ & $\mathrm{X}$ & & & & & & & & & $\mathrm{X}$ & $\mathrm{X}$ & $\mathrm{X}$ & & $\mathrm{X}$ & & $35 \mathrm{C}$ \\
\hline $5 K$ contorta var. elongata & $\mathrm{X}$ & & & $\mathrm{X}$ & & $\mathrm{X}$ & & & & & & & & & & $\mathrm{X}$ & & $\mathrm{X}$ & & & $25 \mathrm{R}$ \\
\hline 6 K. dianae & & $\mathrm{X}$ & $\mathrm{X}$ & & $\mathrm{X}$ & & $\mathrm{X}$ & $\mathrm{X}$ & $\mathrm{X}$ & & & & & $\mathrm{X}$ & & & & & & & $35 \mathrm{C}$ \\
\hline 7 K. lunaris & $\mathrm{X}$ & $\mathrm{X}$ & & & & $\mathrm{X}$ & & & $X$ & $\mathrm{X}$ & & & & & $\mathrm{X}$ & $\mathrm{X}$ & & $\mathrm{X}$ & & $\mathrm{X}$ & $45 \mathrm{C}$ \\
\hline 8 Monoraphidium contortum & $\mathrm{X}$ & $\mathrm{X}$ & & & $\mathrm{X}$ & $\mathrm{X}$ & & & $X$ & $\mathrm{X}$ & & & & & & & & & $X$ & $\mathrm{X}$ & $40 \mathrm{C}$ \\
\hline 9 M. griffithii & $\mathrm{X}$ & & & & & & & & & & & & & & & & & $\mathrm{X}$ & & & $10 \mathrm{R}$ \\
\hline 10 Tetraëdron minimum & & & & & $\mathrm{X}$ & & & & & & & & & & $\mathrm{X}$ & $\mathrm{X}$ & & & $\mathrm{X}$ & & $20 \mathrm{R}$ \\
\hline sub total & 4 & 5 & 2 & 2 & 5 & 4 & 2 & 1 & 4 & 2 & 2 & 2 & 0 & 2 & 4 & 5 & 1 & 3 & 4 & 3 & \\
\hline Coelastraceae & & & & & & & & & & & & & & & & & & & & & \\
\hline 1 Actinastrum aciculare f. minimum * & & & & & & & & & $\mathrm{X}$ & & & & & & & & & & & & $05 \mathrm{R}$ \\
\hline 2 A. hantzschii var. subtile & & & & & $\mathrm{X}$ & & & & & & & & & & & & & $\mathrm{X}$ & & & $10 \mathrm{R}$ \\
\hline 3 Coelastrum microporum & & & $\mathrm{X}$ & $\mathrm{X}$ & & $\mathrm{X}$ & $\mathrm{X}$ & $\mathrm{X}$ & & $\mathrm{X}$ & $\mathrm{X}$ & & & $\mathrm{X}$ & $\mathrm{X}$ & $\mathrm{X}$ & & & & & $50 \mathrm{C}$ \\
\hline 4 C. microporum var. octaedricum & $\mathrm{X}$ & & $\mathrm{X}$ & & $X$ & & $\mathrm{X}$ & & $X$ & $\mathrm{X}$ & & & & & & & $\mathrm{X}$ & & $\mathrm{X}$ & & $40 \mathrm{C}$ \\
\hline 5 C. prosbocideum & $\mathrm{X}$ & & & & & & & & & & & & & & & & & & & $\mathrm{X}$ & $10 \mathrm{R}$ \\
\hline 6 C.pseudomicroporum & & $\mathrm{X}$ & $\mathrm{X}$ & $\mathrm{X}$ & & & & & & $\mathrm{X}$ & & & & & & $\mathrm{X}$ & & & $\mathrm{X}$ & $\mathrm{X}$ & $35 \mathrm{C}$ \\
\hline 7 C.pulchrum & & & $\mathrm{X}$ & $\mathrm{X}$ & $\mathrm{X}$ & $\mathrm{X}$ & & $\mathrm{X}$ & $\mathrm{X}$ & $\mathrm{X}$ & & & & & $\mathrm{X}$ & $\mathrm{X}$ & $\mathrm{X}$ & & $\mathrm{X}$ & & $55 \mathrm{C}$ \\
\hline 8 C. reticulatum & & & & $\mathrm{X}$ & & & & & & & & $\mathrm{X}$ & & $\mathrm{X}$ & & $\mathrm{X}$ & $\mathrm{X}$ & & $\mathrm{X}$ & & $30 \mathrm{C}$ \\
\hline sub total & 2 & 1 & 4 & 4 & 3 & 2 & 2 & 2 & 3 & 4 & 1 & 1 & 0 & 2 & 2 & 4 & 3 & 1 & 4 & 2 & \\
\hline Hydrodictyaceae & & & & & & & & & & & & & & & & & & & & & \\
\hline 1 Monactinus simplex & & & & & $X$ & & $X$ & & $X$ & $X$ & & $\mathrm{X}$ & $\mathrm{X}$ & $X$ & & $\mathrm{X}$ & $\mathrm{X}$ & $\mathrm{X}$ & $X$ & $\mathrm{X}$ & $60 \mathrm{CS}$ \\
\hline 2 Pediastrum duplex var. duplex & & $\mathrm{X}$ & $\mathrm{X}$ & $\mathrm{X}$ & $\mathrm{X}$ & $\mathrm{X}$ & & & & & & & $\mathrm{X}$ & $\mathrm{X}$ & $\mathrm{X}$ & $\mathrm{X}$ & & $\mathrm{X}$ & & & $50 \mathrm{C}$ \\
\hline 3 P. duplex var. gracillimum & $\mathrm{X}$ & $\mathrm{X}$ & $\mathrm{X}$ & $\mathrm{X}$ & & $\mathrm{X}$ & & & & & & & $\mathrm{X}$ & $\mathrm{X}$ & $\mathrm{X}$ & $\mathrm{X}$ & $\mathrm{X}$ & $\mathrm{X}$ & $\mathrm{X}$ & $\mathrm{X}$ & $65 \mathrm{CS}$ \\
\hline
\end{tabular}


Tabela 2 (continuação)

\begin{tabular}{|c|c|c|c|c|c|c|c|c|c|c|c|c|c|c|c|c|c|c|c|c|c|c|}
\hline & \multirow{2}{*}{ Táxons } & \multicolumn{2}{|c|}{$\mathrm{P} 8$} & \multicolumn{2}{|c|}{ P9 } & \multicolumn{2}{|c|}{$\mathrm{P} 10$} & \multicolumn{2}{|c|}{ P11 } & \multicolumn{2}{|c|}{ P14 } & \multicolumn{2}{|c|}{ P16 } & \multicolumn{2}{|c|}{$\mathrm{P} 18$} & \multicolumn{2}{|c|}{$\mathrm{P} 25$} & \multicolumn{2}{|c|}{ P27 } & \multicolumn{2}{|c|}{ P30 } & \multirow[b]{2}{*}{$\mathrm{F} \%$} \\
\hline & & $\mathrm{C}$ & $\mathrm{S}$ & $\mathrm{C}$ & $\mathrm{S}$ & $\mathrm{C}$ & $\mathrm{S}$ & $\mathrm{C}$ & $\mathrm{S}$ & $\mathrm{C}$ & $S$ & $\mathrm{C}$ & $\mathrm{S}$ & $\mathrm{C}$ & $\mathrm{S}$ & $\mathrm{C}$ & $\mathrm{S}$ & $\mathrm{C}$ & $\mathrm{S}$ & $\mathrm{C}$ & $\mathrm{S}$ & \\
\hline \multirow[t]{3}{*}{4} & Stauridium tetras & $\mathrm{X}$ & $\mathrm{X}$ & & & & $\mathrm{X}$ & $\mathrm{X}$ & & $\mathrm{X}$ & & & & & & & & & $\mathrm{X}$ & & $\mathrm{X}$ & $35 \mathrm{C}$ \\
\hline & sub total & 2 & 3 & 2 & 2 & 2 & 3 & 2 & 0 & 2 & 1 & 0 & 1 & 3 & 3 & 2 & 3 & 2 & 4 & 2 & 3 & \\
\hline & Micractiniaceae & & & & & & & & & & & & & & & & & & & & & \\
\hline 1 & Micractinium borhemiense & $\mathrm{X}$ & & & & & & & & & & & & & & & & & & $\mathrm{X}$ & $\mathrm{X}$ & $15 \mathrm{R}$ \\
\hline \multirow[t]{2}{*}{2} & M. pusillum & & & & & & $\mathrm{X}$ & $\mathrm{X}$ & & $\mathrm{X}$ & & & & & $\mathrm{X}$ & & $\mathrm{X}$ & & & & $\mathrm{X}$ & $30 \mathrm{C}$ \\
\hline & Oocystaceae & & & & & & & & & & & & & & & & & & & & & \\
\hline$\overline{1}$ & Franceia cf. droescheri & & & & & $\mathrm{X}$ & $\mathrm{X}$ & & & $\mathrm{X}$ & $\mathrm{X}$ & & & $\bar{X}$ & & & & & & & & $25 \mathrm{R}$ \\
\hline 2 & Lagerheimia ciliata & $\mathrm{X}$ & & & & & & & & & $\mathrm{X}$ & & $\mathrm{X}$ & & & $\mathrm{X}$ & $\mathrm{X}$ & & & $\mathrm{X}$ & $\mathrm{X}$ & $35 \mathrm{C}$ \\
\hline 3 & Oocystis borgei & $\mathrm{X}$ & $\mathrm{X}$ & $\mathrm{X}$ & $\mathrm{X}$ & $\mathrm{X}$ & & $\mathrm{X}$ & & & $\mathrm{X}$ & & & & & & $\mathrm{X}$ & & $\mathrm{X}$ & $\mathrm{X}$ & $\mathrm{X}$ & $55 \mathrm{C}$ \\
\hline 4 & O. lacustris & & & & & & & $\mathrm{X}$ & & $\mathrm{X}$ & $\mathrm{X}$ & & & & & & & & & & & $15 \mathrm{R}$ \\
\hline 5 & O. marssonii & $\mathrm{X}$ & & $\mathrm{X}$ & $\mathrm{X}$ & & $\mathrm{X}$ & $\mathrm{X}$ & $\mathrm{X}$ & & $\mathrm{X}$ & & & & & $\mathrm{X}$ & & $\mathrm{X}$ & $\mathrm{X}$ & $\mathrm{X}$ & $\mathrm{X}$ & $60 \mathrm{CS}$ \\
\hline \multirow[t]{3}{*}{6} & Tetrachlorella alternans & & & & & $\mathrm{X}$ & $\mathrm{X}$ & $\mathrm{X}$ & & & & & & & & & & $\mathrm{X}$ & $\mathrm{X}$ & $\mathrm{X}$ & $\mathrm{X}$ & $35 \mathrm{C}$ \\
\hline & sub total & 3 & 1 & 2 & 2 & 3 & 3 & 4 & 1 & 2 & 5 & 0 & 1 & 1 & 0 & 2 & 2 & 2 & 3 & 4 & 4 & \\
\hline & Radiococcaceae & & & & & & & & & & & & & & & & & & & & & \\
\hline 1 & Coenocystis subcylindrica* & $\mathrm{X}$ & & & & & & & & & & & & & & $\mathrm{X}$ & & & & & & $10 \mathrm{R}$ \\
\hline 2 & $\begin{array}{l}\text { Eutetramorus fottii } \\
\text { Treubariaceae }\end{array}$ & & & & $\mathrm{X}$ & & & & $\mathrm{X}$ & $\mathrm{X}$ & & & & & & & & & & & $\mathrm{X}$ & $20 \mathrm{R}$ \\
\hline 1 & Treubaria schmidlei & & & & & & $\mathrm{X}$ & & & & & & & $\mathrm{X}$ & $\mathrm{X}$ & $\mathrm{X}$ & & & & & & $20 \mathrm{R}$ \\
\hline & Total de táxons & 14 & 11 & 12 & 15 & 15 & 17 & 13 & 7 & 16 & 14 & 6 & 7 & 6 & 11 & 15 & 18 & 11 & 12 & 19 & 16 & \\
\hline
\end{tabular}

e as menores frequências de ocorrência foram Micractiniaceae, Radiococcaceae e Treubariaceae.

$\mathrm{O}$ estudo florístico das Chlorococcales (exceto Scenedesmaceae) de amostras provenientes de 10 pesqueiros da Região Metropolitana de São Paulo permitiu a identificação de 38 táxons, distribuídos em oito famílias, 19 gêneros e quatro variedades que não as típicas das espécies (tabelas 2 e 3). As maiores riquezas de espécies, 18 e 19 táxons, foram registrados nos pesqueiros P25 (época de seca) e P30 (época de chuva), respectivamente. Já a menor riqueza, seis táxons, foi registrada nos pesqueiros P16 e P18 (época de chuva) (tabela 2).

\section{BOTRYOCOCCACEAE}

\section{Botryococcus Kützing 1849}

Chave para identificação das espécies de Botryococcus em pesqueiros da RMSP

1. Mucilagem colonial com prolongamentos espinhosos irregulares B. terribilis

1. Mucilagem colonial sem qualquer tipo de prolongamento B. braunii
Botryococcus braunii Kützing, Spec. algar. 892. 1849. Figuras 2-3

Colônias esféricas ou irregulares, 56,7-70,0 compr., 52,6-60,0 $\mu \mathrm{m}$ diâm.; células obovadas, unidas por pedúnculos de mucilagem, 6,0-9,0 $\mu \mathrm{m}$ compr., 5,6-4,0 $\mu \mathrm{m}$ diâm., envolvidas totalmente ou até $3 / 4$ por bainha mucilaginosa estratificada em forma de copo; cloroplasto parietal; pirenóide não observado; gotas de óleo presente no interior das células.

Material examinado: BRASIL. São Paulo: São Paulo, Pesqueiro 9, 17-IX-2001, K.E. Esteves s.n. (SP400163); Pesqueiro 14, 28-II-2002, K.E. Esteves s.n. (SP391352); Pesqueiro 16, 25-IX-2001, K.E. Esteves s.n. (SP400156); idem, 22-III-2002, K.E. Esteves s.n. (SP391354); Pesqueiro 30, 19-III-2002, K.E. Esteves S.n. (SP400158).

Para separar as espécies de Botryococcus, Komárek \& Marvan (1992) utilizaram a forma e dimensões celulares, a forma da bainha mucilaginosa e a ausência ou presença de pirenóide. Segundo estes autores $B$. braunii assemelha-se a $B$. neglectus (W.West \& G.S.West) Komárek \& Marvan, mas difere pelas dimensões celulares menores $(4,0-5,0 \mu \mathrm{m}$ compr. 
Tabela 3. Resumo do número de táxons por família nas épocas de chuva e seca nos dez pesqueiros estudados, Região Metropolitana de São Paulo, Brasil.

Table 3. Summary of the number of taxa per family during rainfall and drought periods in the ten fishing ponds studied, Metropolitan Region of São Paulo, Brazil.

\begin{tabular}{lcc}
\hline Família & Táxons & Gêneros \\
\hline Botryococcaceae & 5 & 2 \\
Chlorellaceae & 10 & 4 \\
Coelastraceae & 8 & 2 \\
Hydrodictyaceae & 4 & 3 \\
Micractiniaceae & 2 & 1 \\
Oocystaceae & 6 & 4 \\
Radiococcaceae & 2 & 2 \\
Treubariacae & 1 & 1 \\
\hline
\end{tabular}

e 1,8-3,2 $\mu$ m diâm.) e células completamente envoltas pela mucilagem nesta última espécie. As populações dos pesqueiros analisadas concordam com a descrição apresentada por Komárek \& Marvan (1992) quanto a forma e dimenções celulares, no entanto, as dimensões coloniais foram maiores (acima de $100 \mu \mathrm{m}$ ) nas populações estudadas por estes autores.

Botryococcus terribilis Komárek \& Marvan, Arch. Protistenkd. 141: 92. 1992.

\section{Figuras 4-5}

Colônias irregulares, compostas por subcolônias conectadas por cordões mucilaginosos, 52,6-117,4 $\mu \mathrm{m}$ compr., 48,6-121,5 $\mu \mathrm{m}$ de diâm.; células obovadas, densamente aglomeradas, dispostas radialmente na colônia; células encobertas totalmente por mucilagem colonial; prolongamentos espiniformes irregulares, 8,1-36,4 $\mu \mathrm{m}$ compr.; cloroplasto parietal e pirenóide não observados.

Material examinado: BRASIL. São PaUlo: São Paulo, Pesqueiro 8, 21-II-2002, K.E. Esteves s.n. (SP391348); Pesqueiro 9, 17-IX-2001, K.E. Esteves s.n. (SP400163); idem, 21-II-2002, K.E. Esteves s.n. (SP391349); Pesqueiro 10, 19-IX-2001, K.E. Esteves s.n. (SP400159); Pesqueiro 14, 24-IX-2001, K.E. Esteves s.n. (SP400161); Pesqueiro 16, 25-IX-2001, K.E. Esteves s.n. (SP400156); idem, 22-III-2002, K.E. Esteves s.n. (SP391354); Pesqueiro 27, 19-III-2002, K.E. Esteves s.n. (SP391358).

Segundo Komárek \& Marvan (1992), B. terribilis assemelha-se morfologicamente a B. neglectus (W. \& G.S. West) Komárek \& Marvan, pela capacidade de formar processos gelatinosos na superfície da colônia. Em B. neglectus estes processos tem a forma glandular, enquanto que em $B$. terribilis são longos, espiniformes, ramificados ou não. Além disso, segundo estes mesmos autores, $B$. neglectus possui colônias e células menores (até $50 \mu \mathrm{m}$ diam. e 4,0-5,0 × 1,8-3,2 $\mu \mathrm{m}$, respectivamente) que $B$. terribilis, e ocorrem em ambientes oligo ou mesotróficos, levemente ácidos e com ocorrência muito provavelmente restrita a regiões temperadas do Hemisfério-Norte.

Nas populações analisadas nos pesqueiros, foi difícil visualizar as células em função da mucilagem colonial ampla, semelhante ao observado por Rodrigues (2008), no entanto, os prolongamentos espiniformes das populações dos pesqueiros foram maiores $(2,0-4,5 \mu \mathrm{m})$, o que difere das populações encontradas por Rodrigues (2008).

Dictyosphaerium Nägeli 1849

Chave para identificação das espécies de Dictyosphaerium em pesqueiros da RMSP

1. Células adultas esféricas.... D. pulchellum

1. Células adultas oblongas

2. Fios de mucilagem inseridos na porção mais alargada da célula ............D. ehrenbergianum

2. Fios de mucilagem inseridos na porção basal da célula D. tetrachotomum

Dictyosphaerium ehrenbergianum Nägeli, Gatt. Enzell. Alg. p. 74, pl. II, 1849.

Figuras 6-7

Colônias formadas por grupos de 4 células unidas por fios de mucilagem; células adultas oblongas, 6,4-8,1 $\mu \mathrm{m}$ compr., 4,0-6,5 $\mu \mathrm{m}$ diâm.; fios de mucilagem inseridos na porção mais alargada da célula; cloroplasto único poculiforme; 1 pirenóide. 
Material examinado: BRASIL. São Paulo: São Paulo, Pesqueiro 9, 17-IX-2001, K.E. Esteves s.n. (SP400163); Pesqueiro 10, 19-IX-2001, K.E. Esteves s.n. (SP400159); Pesqueiro 11, 26-II-2002, K.E. Esteves s.n. (SP391350); Pesqueiro 18, 10-X-2001, K.E. Esteves s.n. (SP400160); Pesqueiro 25, 8-X-2001, K.E. Esteves s.n. (SP400153), idem, 21-III-2002, K.E. Esteves s.n. (SP391357); Pesqueiro 27, 19-III-2002, K.E. Esteves s.n. (SP391358); Pesqueiro 30, 19-III-2002, K.E. Esteves s.n. (SP400158).

Sant'Anna (1984) comentou que a identificação de espécies de Dictyosphaerium deve ser baseada na forma das células adultas e não na dos autósporos que tendem a sofrer mudanças à medida que crescem. Nas populações de $D$. ehrenbergianum estudadas foram observados indivíduos adultos que apresentaram características semelhantes às descritas por Sant'Anna (1984).

Dictyosphaerium pulchellum H.C. Wood, Smithson. Contrib. Knowl. 19(3): 84. 1873.

Figuras 8-9

Colônias formadas por grupos de 4 células unidas por fios de mucilagem; células adultas esféricas, 3,6-8,1 $\mu \mathrm{m}$ diâm.; cloroplasto único poculiforme, ocupando metade da célula ou mais; 1 pirenóide basal.

Material examinado: BRASIL. São Paulo: São Paulo, Pesqueiro 8, 17-IX-2001, K.E. Esteves s.n. (SP400164); Pesqueiro 9, 17-IX-2001, K.E. Esteves s.n. (SP400163); idem, 21-II-2002, K.E. Esteves s.n. (SP391349); Pesqueiro 10, 19-IX-2001, K.E. Esteves s.n. (SP400159); idem, 26-II-2002, K.E. Esteves s.n. (SP400154); Pesqueiro 11, 19-IX-2001, K.E. Esteves s.n. (SP400162); idem, 26-II-2002, K.E. Esteves s.n. (SP391350); Pesqueiro 14, 24-IX-2001, K.E. Esteves s.n. (SP400161); idem, 28-II-2002, K.E. Esteves s.n. (SP391352); Pesqueiro 18, 10-X-2001, K.E. Esteves s.n. (SP400160); idem, 19-III-2002, K.E. Esteves s.n. (SP391359); Pesqueiro 25, 8-X-2001, K.E. Esteves s.n. (SP400153); idem, 21-III-2002, K.E. Esteves s.n. (SP391357); Pesqueiro 27, 10-X-2001, K.E. Esteves s.n. (SP400155); idem, 19-III-2002, K.E. Esteves s.n. (SP391358); Pesqueiro 30, 10-X-2001, K.E. Esteves s.n. (SP400157); idem, 19-III-2002, K.E. Esteves s.n. (SP400158).

Dictyosphaerium pulchellum caracteriza-se por apresentar células adultas esféricas, autósporos paralelos a oblongo-assimétricos, células jovens oblongas até ovadas. Nas populações estudadas, todas estas características foram observadas.

Dictyosphaerium tetrachotomum Printz, Skr. VidensSelsk. Kristiania, Mat.-Naturv. K1. 1913(6): 24, pl. I, fig. 5 e 6.1914.

Figuras 10-11

Colônias formadas por grupos de 4 células unidas por fios de mucilagem; 60,7-112,2 $\mu$ m diâm.; células adultas oblongas-alargadas, 8,1-9,7 compr., 6,4-8,1 $\mu \mathrm{m}$ diâm., fios mucilaginosos inseridos na porção basal da célula; cloroplasto único poculiforme; 1 pirenóide.

Material examinado: BRASIL. São Paulo: Pesqueiro 10, 26-II-2002, K.E. Esteves s.n. (SP400154); Pesqueiro 11, 19-IX-2001, K.E. Esteves s.n. (SP400162); Pesqueiro 14, 28-II-2002, K.E. Esteves s.n. (SP391352); Pesqueiro 25, 8-X-2001, K.E. Esteves s.n. (SP400153); idem, 21-III-2002, K.E. Esteves s.n. (SP391357); Pesqueiro 30, 19-III-2002, K.E. Esteves s.n. (SP400158).

Segundo Treviño (2008), D. tetrachotomum diferencia-se de $D$. pulchellum por suas células adultas ovais e pelo giro de $180^{\circ}$ de seus autósporos depois de serem liberados da parede da célula mãe. Nas populações estudadas não foram observados autósporos, mas a forma oblonga-alargadas das células adultas de $D$. tetrachotomum e a forma de inserção dos fios mucilaginosos foram suficientes para diferenciar estas duas espécies.

\section{CHLORELLACEAE}

Ankistrodesmus Corda 1838

Chave para identificação das espécies de Ankistrodesmus em pesqueiros da RMSP

1. Colônias com células lunadas A. bibraianus

1. Colônias com células fusiformes

2. Células fusiformes arqueadas ............... A. gracilis

2. Células fusiformes retas .................... A. fusiformis

Ankistrodesmus bibraianus (Reinsch) Korshikov, Protococcineae 302. 1953 Selenastrum bibraianum Reinsch, Algenfl. Franken. 64. 1867. Figuras 12-13

Colônias formadas por 4-8-16-32 células unidas por suas margens convexas; células lunadas, afilando 
gradualmente em direção aos ápices, 7,2-16,2 $\mu \mathrm{m}$ de distância entre os ápices, 2,4-4,0 $\mu \mathrm{m}$ diâm.; cloroplasto único, parietal; pirenóide ausente.

Material examinado: BRASIL. São PAUlo: São Paulo, Pesqueiro 9, 17-IX-2001, K.E. Esteves s.n. (SP400163); idem, 21-II-2002, K.E. Esteves s.n. (SP391349); Pesqueiro 10, 26-II-2002, K.E. Esteves s.n. (SP400154); Pesqueiro 11, 26-II-2002, K.E. Esteves s.n. (SP391350); Pesqueiro 16, 25-IX-2001, K.E. Esteves s.n. (SP400156); idem, 22-III-2002, K.E. Esteves s.n. (SP391354); Pesqueiro 18, 10-X-2001, K.E. Esteves s.n. (SP400160); Pesqueiro 25, 8-X-2001, K.E. Esteves s.n. (SP400153); idem, 21-III-2002, K.E. Esteves s.n. (SP391357).

Ankistrodesmus e Selenastrum Reinsch, ambos coloniais, diferenciam-se pela disposição das células na colônia, forma e curvatura das células (Nogueira 1991). Em Selenastrum as células são lunadas, com a porção convexa voltada para o centro da colônia. Em Ankistrodesmus, as células são fusiformes alongadas, arranjadas em fascículos ou radialmente dispostas. Mas, Korsikov (1953), Komarková-Legnerová (1969), Komárek \& Fott (1983), Hindák (1984) e Sant'Anna (1984) não consideraram nítidas as características usadas para diferenciar esses dois gêneros, e, assim, consideraram Selenastrum sinônimo de Ankistrodesmus. As espécies de Ankistrodesmus descritas neste trabalho foram identificadas de acordo com Komárek \& Fott (1983). As populações analisadas concordam com o material descrito por Komárek \& Fott (1983), entretanto, apresentaram colônias com numerosas células (32).

Ankistrodesmus fusiformis Corda sensu Korshikov, Protococcinae 300. 1953.

Figura 14

Colônias formadas por 4 ou mais células dispostas em cruz ou radialmente; células fusiformes retas, afilando gradualmente em direção aos ápices, 40,0-44,5 $\mu \mathrm{m}$ compr.; 1,0-1,6 $\mu \mathrm{m}$ diâm.; cloroplasto único parietal, pirenóide ausente.

Material examinado: BRASIL. SãoPaulo: Pesqueiro 16, 22-III-2002, K.E. Esteves s.n. (SP391354); Pesqueiro 30, 10-X-2001, K.E. Esteves s.n. (SP400157).

Ankistrodesmus gracilis (Reinsch) Korshikov, Protococcineae 305. 1953 ESelenastrum gracile Reinsch, Algenfl. Franken. 64. 1867.

Figuras 15-16

Colônias formadas por 16 células, lados convexos orientados para o centro da colônia; mucilagem colonial hialina; células fusiformes arqueadas, afilando gradualmente em direção aos ápices; 4,8-15,0 $\mu \mathrm{m}$ de distância entre os ápices, 1,0-2,0 $\mu \mathrm{m}$ diâm.; cloroplasto único, parietal; pirenóide ausente.

Material examinado: BRASIL. São PAUlo: São Paulo, Pesqueiro 8, 17-IX-2001, K.E. Esteves s.n. (SP400164); Pesqueiro 14, 28-II-2002, K.E. Esteves s.n. (SP391352); Pesqueiro 16, 25-IX-2001, K.E. Esteves s.n. (SP400156); Pesqueiro 30, 19-III-2002, K.E. Esteves s.n. (SP400158).

As populações analisadas diferem da literatura (Komárek 1983, Komárek \& Fott 1983, Hindák 1984, Sant'Anna 1984, Nogueira 1991, Rodrigues 2008) pelas dimensões celulares que apresentaram a distância entre os ápices muito pequena $(4,8 \mu \mathrm{m})$, sendo que na maioria das células os ápices quase se tocavam.

Kirchneriella Schmidle 1893

Chave para identificação das espécies de Kirchneriella em pesqueiros da RMSP

1. Células irregularmente distribuídas na colônia

2. Células com incisão mediana em forma de "V" K. aperta

2. Células com incisão mediana em forma de "U" K. lunaris

1. Células com disposição definida na colônia

3. Células lunadas, dispostas radialmente, com lados convexos voltados para periferia da colônia K. dianae

3. Células cilíndricas torcidas em hélice, dispostas aos pares na colônia K. contorta var. elongata

Kirchneriella aperta Teiling, Svensk Bot. Tidskr. 6(2): 276, fig. 9. 1912.

Figura 17

Colônias formadas por 4-16-32 células, dispostas irregularmente na colônia, mucilagem hialina incospícua; células lunadas, 7,0-9,7 $\mu \mathrm{m}$ compr., 4,8-6,0 $\mu \mathrm{m}$ diâm., 3,2-4,0 $\mu \mathrm{m}$ de distância entre os ápices; células com incisão mediana em forma de "V", ápices afilados gradualmente num mesmo plano; cloroplasto único parietal, pirenóide não observado.

Material examinado: BRASIL. São PaUlo: São Paulo, Pesqueiro 8, 17-IX-2001, K.E. Esteves s.n. (SP400164); Pesqueiro 10, 19-IX-2001, 

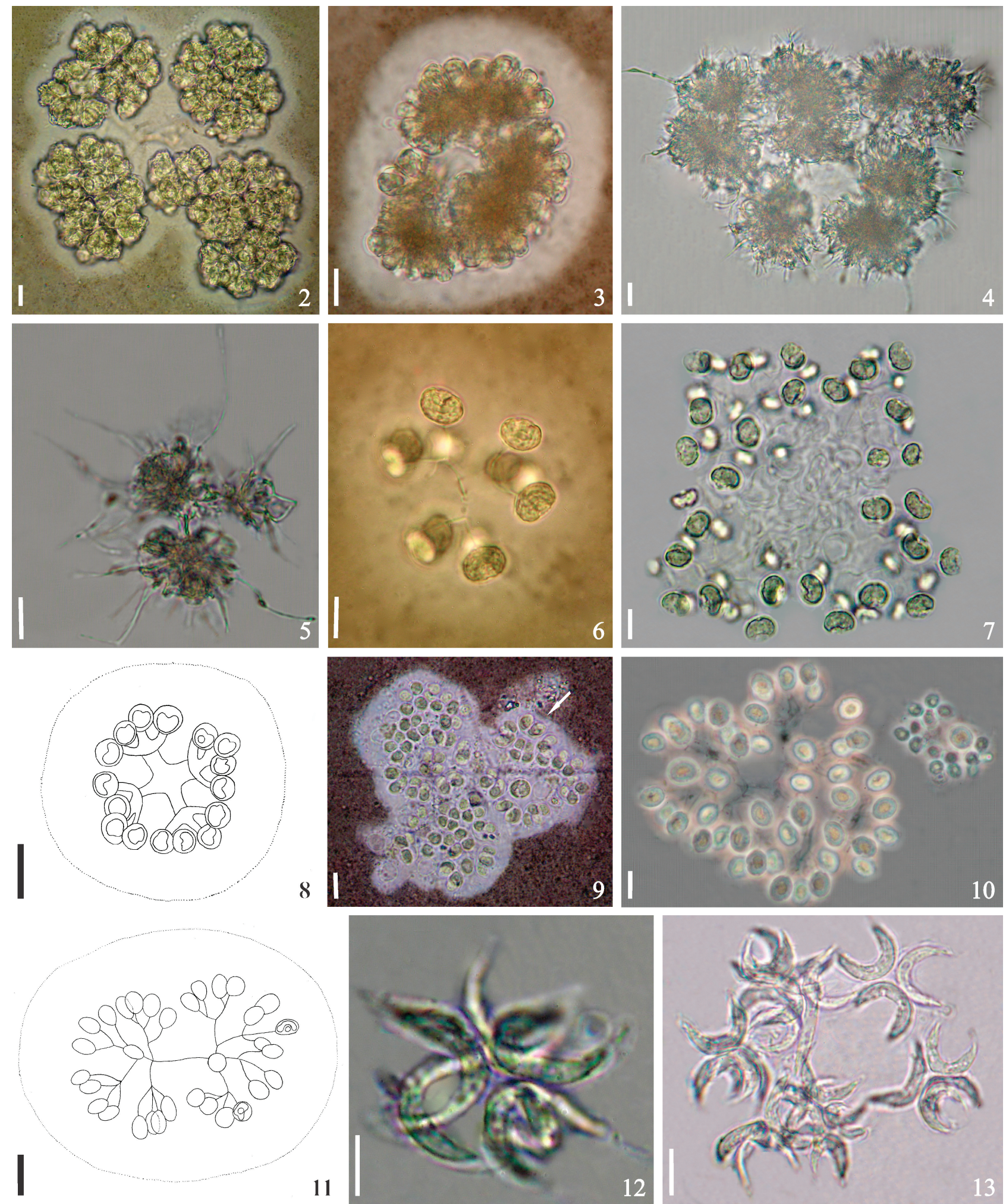

Figuras 2-13. Espécies de Chlorococcales de pesqueiros da Região Metropolitana de São Paulo, SP, Brasil. 2-3. Botryococcus braunii. 4-5. B. terribilis. 6-7. Dictyosphaerium ehrenbergianum. 8-9. D. pulchellum. 9. seta indicando reprodução celular. 10-11. D. tetrachotomum. 11. Contraste de fase. 12-13. Ankistrodesmus bibraianus. Barras das escalas $=10 \mu \mathrm{m}$.

Figures 2-13. Chlorococcales species found in the fishing ponds in the Metropolitan Region of São Paulo, São Paulo State, Brazil. 2-3. Botryococcus braunii. 4-5. B. terribilis. 6-7. Dictyosphaerium ehrenbergianum. 8-9. D. pulchellum. 9. Arrow indicating cell reproduction. 10-11. D. tetrachotomum. 11. Phase contrast. 12-13. Ankistrodesmus bibraianus. Scale bars $=10 \mu \mathrm{m}$. 
K.E. Esteves s.n. (SP400159); idem, 26-II-2002, K.E. Esteves s.n. (SP400154); Pesqueiro 25, 8-X-2001, K.E. Esteves s.n. (SP400153); idem, 21-III-2002, K.E. Esteves s.n. (SP391357); Pesqueiro 27, 19-III-2002, K.E. Esteves s.n. (SP391358); Pesqueiro 30, 10-X-2001, K.E. Esteves s.n. (SP400157); idem, 19-III-2002, K.E. Esteves s.n. (SP400158).

Kirchneriella contorta var. elongata (G.M. Smith) Komárek, Arch Hydrobiol. Suppl. 56(2): 256. 1979 $\equiv$ Kirchneriella elongata G.M. Smith, Bull. Torrey Bot. Club 43: 473, pl. 24, fig. 7. 1916.

Figura 18

Colônias formadas por 8-16-32-64 células dispostas aos pares na mucilagem; mucilagem hialina inconspícua, células cilíndricas, torcidas em hélice com 1 volta, 1,5-2,0 $\mu \mathrm{m}$ diâm., 7,0-8,0 $\mu \mathrm{m}$ de distância entre os ápices, 4,0-5,0 $\mu \mathrm{m}$ de altura da hélice; cloroplasto único parietal, pirenóide ausente.

Material examinado: BRASIL. São Paulo: São Paulo, Pesqueiro 8, 21-II-2002, K.E. Esteves s.n. (SP391348); Pesqueiro 9, 17-IX-2001, K.E. Esteves s.n. (SP400163); Pesqueiro 10, 19-IX-2001, K.E. Esteves s.n. (SP400159); Pesqueiro 25, 8-X-2001, K.E. Esteves s.n. (SP400153); Pesqueiro 27, 10-X-2001, K.E. Esteves s.n. (SP400155).

Kirchneriella contorta var. elongata difere da variedade tipo por apresentar células em forma de parafuso, enquanto que $K$. contorta var. contorta G.M. Smith apresenta células semicirculares. As populações analisadas estão de acordo com o material descrito por Komárek \& Fott (1983).

Kirchneriella dianae (Bohlin) Comas Gonzalez, Acta Bot. Cubana 2: 4. 1980 EKirchneriella lunaris var. dianae Bohlin, Bih. K.Svenska Vet. Akad. Handl. 23: 20. fig. 28-30. 1897.

Figura 19

Colônias formadas por 4-16-32 células dispostas radialmente com lados convexos voltados para periferia da colônia; mucilagem hialina inconspícua; células lunadas, contorno celular ovóide, 7,0-9,0 $\mu \mathrm{m}$ compr.; 2,0-4,5 $\mu \mathrm{m}$ diâm.; 2,0-3,2 $\mu \mathrm{m}$ de distância entre os ápices, 9-11 $\mu \mathrm{m}$ de altura, razão altura/comprimento $1,2 \mu \mathrm{m}$; células com incisão mediana em forma de "U”, ápices afilados gradualmente; cloroplasto único parietal, 1 pirenóide.

Material examinado: BRASIL. São PAULo: São Paulo, Pesqueiro 8, 17-IX-2001, K.E. Esteves s.n. (SP400164); idem, 21-II-2002, K.E. Esteves s.n. (SP391348); Pesqueiro 9, 21-II-2002, K.E. Esteves s.n. (SP391349); Pesqueiro 10, 26-II-2002, K.E. Esteves s.n. (SP400154); Pesqueiro 11, 19-IX-2001, K.E. Esteves s.n. (SP400162); idem, 26-II-2002, K.E. Esteves s.n. (SP391350); Pesqueiro 14, 28-II-2002, K.E. Esteves s.n. (SP391352); Pesqueiro 18, 10-X-2001, K.E. Esteves s.n. (SP400160).

Kirchneriella dianae foi considerada por muitos autores como uma variedade de $K$. lunaris (Kirchner) Mobius. Segundo Comas (1980), em ambas existem diferenças notáveis o suficiente para separá-las como espécies distintas. Kirchneriella dianae possui células cujos ápices são alongados e afilados e os pólos pontiagudos; K. lunaris possui células mais arredondadas, os ápices são curtos e não marcadamente afilados, mas que terminam quase abruptamente pontiagudos e a abertura entre os ápices distintos, em forma de "U" em $K$. dianae e, em forma de "O" em K. lunaris (tabela 4). Nas populaçõs estudadas, $K$. dianae apresentou disposição celular radial dentro da matriz mucilaginosa colonial, característica constante e típica na espécie o que não ocorreu em $K$. lunaris, cujas células estiveram irregularmente ordenadas dentro da mucilagem colonial. As populações analisadas concordam com o material descrito originalmente para $K$. dianae.

Kirchneriella lunaris (Kirchner) K. Möbius, Abh. Senckenberg. Naturf. Ges. 18: 331. $1894 \equiv$ Raphidium convolutum var. lunare Kirchner, Kryptogamenfl. Schlesien 2(1): 114. 1878.

Figuras 20-21

Colônias formadas por 4-16 células irregularmente distribuídas na mucilagem colonial; mucilagem hialina inconspícua; células lunadas, contorno celular circular, 7,0-8,1 $\mu \mathrm{m}$ compr., 4,8 $\mu \mathrm{m}$ diâm., 1,6 $\mu \mathrm{m}$ de distância entre os ápices, 8,1-8,9 $\mu \mathrm{m}$ de altura; razão altura/comprimento $1,0-1,1 \mu \mathrm{m}$; células com incisão mediana em forma de "U", ápices afilados gradualmente; cloroplasto único parietal, pirenóide não observado.

Material examinado: BRASIL. São PAUlo: São Paulo, Pesqueiro 8, 17-IX-2001, K.E. Esteves s.n. (SP400164); idem, 21-II-2002, K.E. Esteves s.n. (SP391348); Pesqueiro 10, 19-IX-2001, K.E. Esteves s.n. (SP400159); Pesqueiro 14, 24-IX-2001, K.E. Esteves s.n. (SP400161); idem, 28-II-2002, K.E. Esteves s.n. (SP391352); Pesqueiro 25, 8-X-2001, K.E. Esteves s.n. (SP400153); idem, 21-III-2002, K.E. Esteves s.n. (SP391357); Pesqueiro 27, 10-X-2001, 
Tabela 4. Comparação do hábito, das características diacríticas, da relação comprimento/largura, e da disposição das células nas colônias de duas espécies de Kirchneriella (a: comprimento, b: largura) (modificado de Comas 1980), Região Metropolitana de São Paulo, Brasil

Table 4. Comparison of habit, diacritical features, length/width ratio, and arrangement of cells in colonies of two species of Kirchneriella (a: length, b: width) (modified Comas 1980), Metropolitan Region of São Paulo, Brazil

\begin{tabular}{|c|c|c|}
\hline & K. dianae & K. lunaris \\
\hline Forma da célula & $\lambda^{--4}$ & 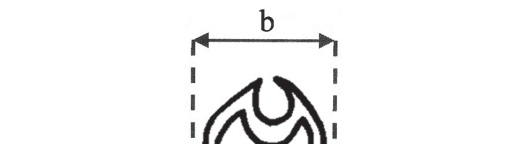 \\
\hline Caracteres diacríticos & $\begin{array}{l}\text { Ápices alongados afilados } \\
\text { Pólos pontiagudos } \\
\text { Abertura em forma de "U" }\end{array}$ & $\begin{array}{l}\text { Ápices curtos afilados } \\
\text { Pólos pontiagudos } \\
\text { Abertura em forma de "O" }\end{array}$ \\
\hline $\mathrm{a} / \mathrm{b}$ & $1,2-1,5 \mu \mathrm{m}$ & $0,8-1,0 \mu \mathrm{m}$ \\
\hline $\begin{array}{l}\text { Disposição celular } \\
\text { na colônia }\end{array}$ & $\begin{array}{c}\text { Células dispostas radialmente na } \\
\text { mucilagem colonial }\end{array}$ & $\begin{array}{c}\text { Células dispostas irregularmente na } \\
\text { mucilagem colonial }\end{array}$ \\
\hline
\end{tabular}

K.E. Esteves s.n. (SP400155); idem, 19-III-2002, K.E. Esteves s.n. (SP391358); Pesqueiro 30, 10-X-2001, K.E. Esteves s.n. (SP400157).

Segundo Comas (1980), a abertura entre os ápices em forma de "O" em K. lunaris é uma das características utilizadas para separá-la de $K$. dianae (tabela 4). No entanto, em 1996 este mesmo autor relatou ter encontrado indivíduos representantes de $K$. lunaris, com abertura entre os ápices em forma de "V" e "U". Nas populações dos pesqueiros estudados foram observadas algumas células com abertura entre os ápices em forma de "U", mas nunca em forma de "V".

Monoraphidium Komárková-Legnerová 1969

Chave para identificação das espécies de Monoraphidium em pesqueiros da RMSP

1. Células fusiformes sigmóides, helicoidais

M. contortum

1. Células fusiformes retas M. griffithii

Monoraphidium contortum (Thuret) KomárkováLegnerová, Stud. Phycol. 104.1969 =Ankistrodesmus contortus Thuret, Mém. Soc. Imp. Sci. Nat. Cherbourg 4: 158, pl. 2, fig. 31. 1856.

Figura 22

Células isoladas, fusiformes, sigmóides, helicoidais com 1,0-1,5 voltas, distância entre os ápices celulares de 8,9-32,4 $\mu \mathrm{m}, 0,8-2,0 \mu \mathrm{m}$ diâm.; cloroplasto único parietal sem pirenóide.

Material examinado: BRASIL. São Paulo: São Paulo, Pesqueiro 8, 17-IX-2001, K.E. Esteves s.n. (SP400164); idem, 21-II-2002, K.E. Esteves s.n. (SP391348); Pesqueiro 10, 19-IX-2001, K.E. Esteves s.n. (SP400159); idem, 26-II-2002, K.E. Esteves s.n. (SP400154); Pesqueiro 14, 24-IX-2001, K.E. Esteves s.n. (SP400161); idem, 28-II-2002, K.E. Esteves s.n. (SP391352); Pesqueiro 30, 10-X-2001, K.E. Esteves s.n. (SP400157); idem, 19-III-2002, K.E. Esteves s.n. (SP400158).

Monoraphidium contortum é morfologicamente semelhante a $M$. irregulare (Smith) Komárková-Legnerová, do qual difere pela distância entre os ápices, que é maior em $M$. irregulare (40,0-72,0 $\mu \mathrm{m})$. As populações analisadas concordam com o material descrito e ilustrado por Komárek \& Fott (1983) para M. contortum.

Monoraphidium griffithii (Berkeley) Komárková -Legnerová, Stud. Phycol. 89. $1969 \equiv$ Closterium griffithii Berkeley, Ann. Mag. Hist. 13, ser. 2: 256, pl. 14, fig 2. 1854.

Figura 23

Células isoladas, fusiformes, retas, com ápices gradualmente afilados, 55,0 $\mu \mathrm{m}$ compr., 2,4 $\mu \mathrm{m}$ diâm.; cloroplasto único parietal sem pirenóide.

Material examinado: Pesqueiro 27, 10-X-2001, K.E. Esteves s.n. (SP400155). 
Tetraëdron Kützing 1845

Tetraëdron minimum (A. Braun) Hansgirg, Hedwigia

27:131. 1988: 591. $1888 \equiv$ Polyedrium minimum

A. Braun, Alg. Unicell: 94. 1855.

Figura 24

Células isoladas, quadrangulares, 8,1 $\mu \mathrm{m}$ diâm., ângulos arredondados, margens levemente côncavas, parede celular pontuada, cloroplasto parietal, pirenóide não observado.

Material examinado: BRASIL. São Paulo: São Paulo, Pesqueiro 10, 26-II-2002, K.E. Esteves s.n. (SP400154); Pesqueiro 25, 8-X-2001, K.E. Esteves s.n. (SP400153); idem, 21-III-2002, K.E. Esteves s.n. (SP391357); Pesqueiro 30, 19-III-2002, K.E. Esteves s.n. (SP400158).

\section{COELASTRACEAE}

Actinastrum Lagerheim 1882

Chave para identificação das espécies de Actinastrum em pesqueiros da RMSP

1. Células fusiformes, 1,6-1,7 $\mu$ m diâm A. aciculare var. aciculare f. minimum

1. Células cilíndricas, 2,0-4,0 $\mu \mathrm{m}$ diâm A. hantzschii var. subtile

Actinastrum aciculare var. aciculare f. minimum (Huber-Pestalozzi) Compère, Bull. Jard. Bot. Natl. Be1g. 46: 228. 1976 $\equiv$ Actinastrum minimum Huber -Pestalozzi, Verh. Int. Ver. Limnol. 4: 357. 1929. Figura 25

Cenóbios estrelados, formados por 8 células radiando de um centro comum; células fusiformes, retas, gradualmente afiladas em direção ao ápice, 12,9-20,2 $\mu \mathrm{m}$ compr., 1,6-1,7 $\mu \mathrm{m}$ diâm.; cloroplasto único, parietal; pirenóide não observado.
Material examinado: BRASIL. São Paulo: São Paulo, Pesqueiro 14, 28-II-2002, K.E. Esteves s.n. (SP391352).

Segundo Sant'Anna (1984), as características usadas na delimitação das espécies e variedades de Actinastrum são: morfologia celular, tipo de ápice (truncado, afilado, arredondado) e proporção comprimento/largura celular. Actinastrum aciculare difere de $A$. hantzschii Lagerheim pela forma da célula, fusiforme com ápices pontiagudos em $A$. aciculare $\mathrm{e}$ cilíndrica atenuada em direção ao ápice, mas com ápices arredondados em $A$. hantzschii.

Actinastrum aciculare var. aciculare f. minimum difere da forma aciculare pela menor dimensão celular. Segundo Komárek \& Fott (1983), 20-25 $\mu$ m compr., 3-5 diâm. na forma aciculare e 7-20 $\mu \mathrm{m}$ compr., 1,0-2,8 $\mu$ m diâm., na forma minimum. As populações analisadas concordam com o material descrito e ilustrado por Komárek \& Fott (1983) para Actinastrum aciculare var. aciculare f. minimum.

Actinastrum hantzschii Lagerheim var. subtile Woloszynska, Rozpr. Wydz. Akad. Umiej. 11B: 227. 1911.

Figura 26

Cenóbios estrelados, formados por 8 células radiando de um centro comum; células cilíndricas, afilando gradualmente em direção ao ápice, 16,0-30,7 $\mu \mathrm{m}$ compr., 2,0-4,0 $\mu \mathrm{m}$ diâm.; cloroplasto único, parietal; 1 pirenóide na região mediana da célula.

Material examinado: BRASIL. São PAUlo: São Paulo, Pesqueiro 10,26-II-2002,K.E. Esteves s.n. (SP400154); Pesqueiro 27, 10-X-2001, K.E. Esteves s.n. (SP400155).

Actinastrum hantzschii var. subtile difere da var. hantzschii por apresentar maior relação comprimento/ largura das células e ápices mais afilados. As populações analisadas concordam com o material descrito e ilustrado por Komárek \& Fott (1983).

Coelastrum Nägeli in Kützing 1849

Chave para identificação das espécies de Coelastrum em pesqueiros da RMSP

1. Células unidas diretamente por suas paredes, sem processo de união

2. Cenóbios tetraédricos ou octaédricos C. microporum var. octaedricum

2. Cenóbios esféricos C. microporum

1. Células unidas por processos de ligação

3. Cenóbios teraédricos, células triangulares em vista lateral C. prosbocideum

3. Cenóbios esféricos, células de outras formas em vista lateral 4. Células ovódies a cuneiformes em vista lateral C. pseudomicroporum 
4. Células de outras formas em vista lateral

5. Células sub-ovadas poliédricas C. pulchrum

5. Células esféricas C. reticulatum

Coelastrum microporum Nägeli in A. Braun, Alg. Unicell: 70 adn., 73. 1855.

Figura 27

Cenóbios esféricos, formados por 8-16-32 células; mucilagem não observada; células esféricas, 9,7-12,1 $\mu \mathrm{m}$ diâm.; células unidas diretamente por suas paredes, sem processo de união; pequenos espaços intercelulares (no máximo iguais a metade do diâmetro celular); cloroplasto único, parietal com 1 pirenóide central.

Material examinado: BRASIL. SÃo PAULo: São Paulo, Pesqueiro 8, 21-II-2002, K.E. Esteves s.n. (SP391348); Pesqueiro 9, 17-IX-2001, K.E. Esteves s.n. (SP400163); idem, 21-II-2002, K.E. Esteves s.n. (SP391349); Pesqueiro 10, 19-IX-2001, K.E. Esteves s.n. (SP400159); idem, 26-II-2002, K.E. Esteves s.n. (SP400154); Pesqueiro 11, 19-IX-2001, K.E. Esteves s.n. (SP400162); idem, 26-II-2002, K.E. Esteves s.n. (SP391350); Pesqueiro 14, 24-IX-2001, K.E. Esteves s.n. (SP400161); Pesqueiro 16, 22-III-2002, K.E. Esteves s.n. (SP391354); Pesqueiro 18, 10-X-2001, K.E. Esteves s.n. (SP400160); Pesqueiro 25, 8-X-2001, K.E. Esteves s.n. (SP400153); idem, 21-III-2002, K.E. Esteves s.n. (SP391357).

SegundoComas(1996)e Tell(2001), C.microporum caracteriza-se por apresentar células tipicamente esféricas, sem processos de união entre as células vizinhas, ou seja, unidas diretamente por suas paredes, concordando perfeitamente com o material observado nas populações estudadas.

\section{Coelastrum microporum var. octaedricum (Skuja)}

Sodomkova, Acta Universitatis Carolinae-Biologica 1970: 485. 1972 E Coelastrum octaedricum Skuja, Symb. bot. upsal. 9/3: 140. 1948.

Figura 28

Cenóbios tetraédricos ou octaédricos, formados por 4-8-16 células, geralmente dispostas em dois planos de modo que cada célula de um plano localiza-se sobre a região de contato entre duas do segundo plano; mucilagem ampla hialina, difluente; células esféricas, 8,0-16,2 $\mu \mathrm{m}$ diâm., unidas diretamente por suas paredes, achatadas na região de contato; espaços intercelulares quadráticos; cloroplasto único, parietal com 1 pirenóide central.
Material examinado: BRASIL. São PaUlo: São Paulo, Pesqueiro 9, 21-II-2002, K.E. Esteves s.n. (SP391349); Pesqueiro 10, 26-II-2002, K.E. Esteves s.n. (SP400154); Pesqueiro 11, 26-II-2002, K.E. Esteves s.n. (SP391350); Pesqueiro 14, 24-IX-2001, K.E. Esteves s.n. (SP400161); idem, 28-II-2002, K.E. Esteves s.n. (SP391352); Pesqueiro 27, 19-III-2002, K.E. Esteves s.n. (SP391358); Pesqueiro 30, 19-III-2002, K.E. Esteves s.n. (SP400158).

Sodomková (1972) não considerou suficientes as características distintivas entre $C$. microporum e C. octaedricum Skuja para mantê-las como espécies diferentes. Então, propôs que C. octaedricum fosse incluída como uma variedade de $C$. microporum (Coelastrum microporum var. octaedricum). Segundo este mesmo autor, C. microporum var. octaedricum difere da var. microporum por apresentar cenóbios cúbicos ou octaédricos como resultado da disposição das células no cenóbio em 2 planos paralelos.

Coelastrum prosbocideum Bohlin in Wittrock, Nordstedt \& Lagerheim, Algae Aquae dulc. Exsicc. 26: 1240.1896.

Figuras 29-31

Cenóbios tetraédricos, formados por 4-8-16-32 células triangulares em vista lateral, 7,2-13,0 $\mu \mathrm{m}$ compr.; pólos externos com espessamento em forma de coroa; 3 processos unindo umas células às outras; espaços intercelulares quadráticos; cloroplasto único parietal com 1 pirenóide central.

Material examinado: BRASIL. São PAULO: Pesqueiro 11,26-II-2002, K.E. Esteves s.n. (SP391350); Pesqueiro 30, 10-X-2001, K.E. Esteves s.n. (SP400157); idem, 19-III-2002, K.E. Esteves s.n. (SP400158).

Coelastrum prosbocideum e Coelastrum sphaericum Nägeli são similares morfologicamente mas geograficamente distintos (Comas 1992). Segundo Sant'Anna (1984), Sodomková em 1972 observou, através de estudos em cultura, toda a amplitude de variabilidade morfológica da espécie $C$. sphaericum. Após ter observado diversas formas de transição desta espécie, concluiu que C. prosbocideum é apenas uma destas formas e que deve ser considerada sinônimo de C. sphaericum. Entretanto, Sant'Anna (1984) encontrou tanto a forma C. sphaericum, com pólo celular truncado e espessamento em coroa, providas 
de nódulos, quanto a forma C. prosbocideum com pólos celulares arredondados e com tubérculos pouco evidentes nas células jovens, em populações do Estado de São Paulo e as identificou como C. sphaericum, por concordar com Sodomková (1972). Porém, de acordo com Comas (1992), C. prosbocideum ocorre em lagos eutróficos de regiões tropicais, enquanto C. sphaericum ocorre em lagos de zonas temperadas. As populações analisadas apresentaram características de C. prosbocideum e foram identificadas como tal por concordamos com Comas (1992) quanto a independência deste táxon em relação a C. sphaericum.

Coelastrum pseudomicroporum Koršikov, Protococcinae, 348. 1953.

Figuras 32-33

Cenóbios esféricos, formados por 8-16-32 células; mucilagem não observada; células ovóides a cuneiformes em vistas lateral, esféricas em vista apical, unidas por 5-6 processos 9,7-15,0 $\mu \mathrm{m}$ compr., 8,1-10,5 $\mu \mathrm{m}$ diâm.; espaços intercelulares presentes; cloroplasto único, parietal com 1 pirenóide central.

Material examinado: BRASIL. São Paulo: São Paulo, Pesqueiro 8, 17-IX-2001, K.E. Esteves s.n. (SP400164); Pesqueiro 9, 17-IX-2001, K.E. Esteves s.n. (SP400163); Pesqueiro 11, 26-II-2002, K.E. Esteves s.n. (SP391350); Pesqueiro 14, 24-IX-2001, K.E. Esteves s.n. (SP400161); Pesqueiro 25, 8-X-2001, K.E. Esteves s.n. (SP400153); Pesqueiro 30, 10-X-2001, K.E. Esteves s.n. (SP400157); idem, 19-III-2002, K.E. Esteves s.n. (SP400158).

Coelastrum pseudomicroporum é morfologicamente semelhante a $C$. astroideum De Notaris, do qual difere pela presença de processos de união entre as células. As populações analisadas não apresentaram variação morfológica e concordaram com a descrição apresentada por Comas (1996).

Coelastrum pulchrum Schmidle var. pulchrum, Ber. dt. bot. Ges. 10: 206. 1892.

\section{Figuras 34}

Cenóbios esféricos, formados por 32 células; mucilagem não observada; células sub-ovadas a poliédricas em vista lateral, esféricas em vista apical, ápice com projeção cônico-truncado, 12,1-14,5 $\mu \mathrm{m}$ compr., 10,5-11,3 $\mu \mathrm{m}$ diâm., 5-6 processos de união entre as células vizinhas; espaços intercelulares presentes; cloroplasto único parietal com 1 pirenóide central.
Material examinado: BRASIL. São PAULo: São Paulo, Pesqueiro 8, 21-II-2002, K.E. Esteves s.n. (SP391348); Pesqueiro 9, 17-IX-2001, K.E. Esteves s.n. (SP400163); idem, 21-II-2002, K.E. Esteves s.n. (SP391349); Pesqueiro 10, 19-IX-2001, K.E. Esteves s.n. (SP400159); idem, 26-II-2002, K.E. Esteves s.n. (SP400154); Pesqueiro 11, 19-IX-2001, K.E. Esteves s.n. (SP400162); Pesqueiro 14, 24-IX-2001, K.E. Esteves s.n. (SP400161); idem, 28-II-2002, K.E. Esteves s.n. (SP391352); Pesqueiro 25, 8-X-2001, K.E. Esteves s.n. (SP400153); idem, 21-III-2002, K.E. Esteves s.n. (SP391357); Pesqueiro 27, 19-III-2002, K.E. Esteves s.n. (SP391358); Pesqueiro 30, 19-III-2002, K.E. Esteves s.n. (SP400158).

De acordo com Comas (1992), C. pulchrum var. pulchrum assemelha-se morfologicamente a C. bohlinianum var. bohlinianum Comas. Coelastrum bohlinianum var. bohlinianum caracteriza-se pelas protuberâncias nos ápices celulares e pela vista polar quadrada das células, formando 4 (raramente 5) processos arranjados em cruz, sendo esta última a característica que a distingue de C. pulchrum. As populações analisadas estão de acordo com os materiais descritos por Comas $(1992,1996)$ e Tell (2001).

Coelastrum reticulatum (Dangeard) Senn var. reticulatum, Bot. Ztg. 57: 66, pl.2, fig.1-10. $1899 \equiv$ Hariotina reticulata Dangeard, Le Botanisteer, sér. 1: 163, pl.7, fig.15-17. 1899.

Figuras 35-37

Cenóbios esféricos, formados por 8-16-32 células; células esféricas em vista lateral, 8,9-9,7 $\mu \mathrm{m}$ diâm.; 5-6 processos longos e cilíndricos em vista apical unindo as células vizinhas; espaços intercelulares presentes; cloroplasto único parietal com 1 pirenóide central.

Material examinado: BRASIL. São PAulo: São Paulo, Pesqueiro 9, 17-IX-2001, K.E. Esteves s.n. (SP400163); Pesqueiro 16, 25-IX-2001, K.E. Esteves s.n. (PS400156); Pesqueiro 18, 10-X-2001, K.E. Esteves s.n. (SP400160); Pesqueiro 25, 8-X-2001, K.E. Esteves s.n. (SP400153); Pesqueiro 27, 19-III-2002, K.E. Esteves s.n. (SP391358); Pesqueiro 30, 19-III-2002, K.E. Esteves s.n. (SP400158).

Coelastrum reticulatum caracteriza-se pelos longos processos gelatinosos que unem as células vizinhas, pela presença de um único processo de 

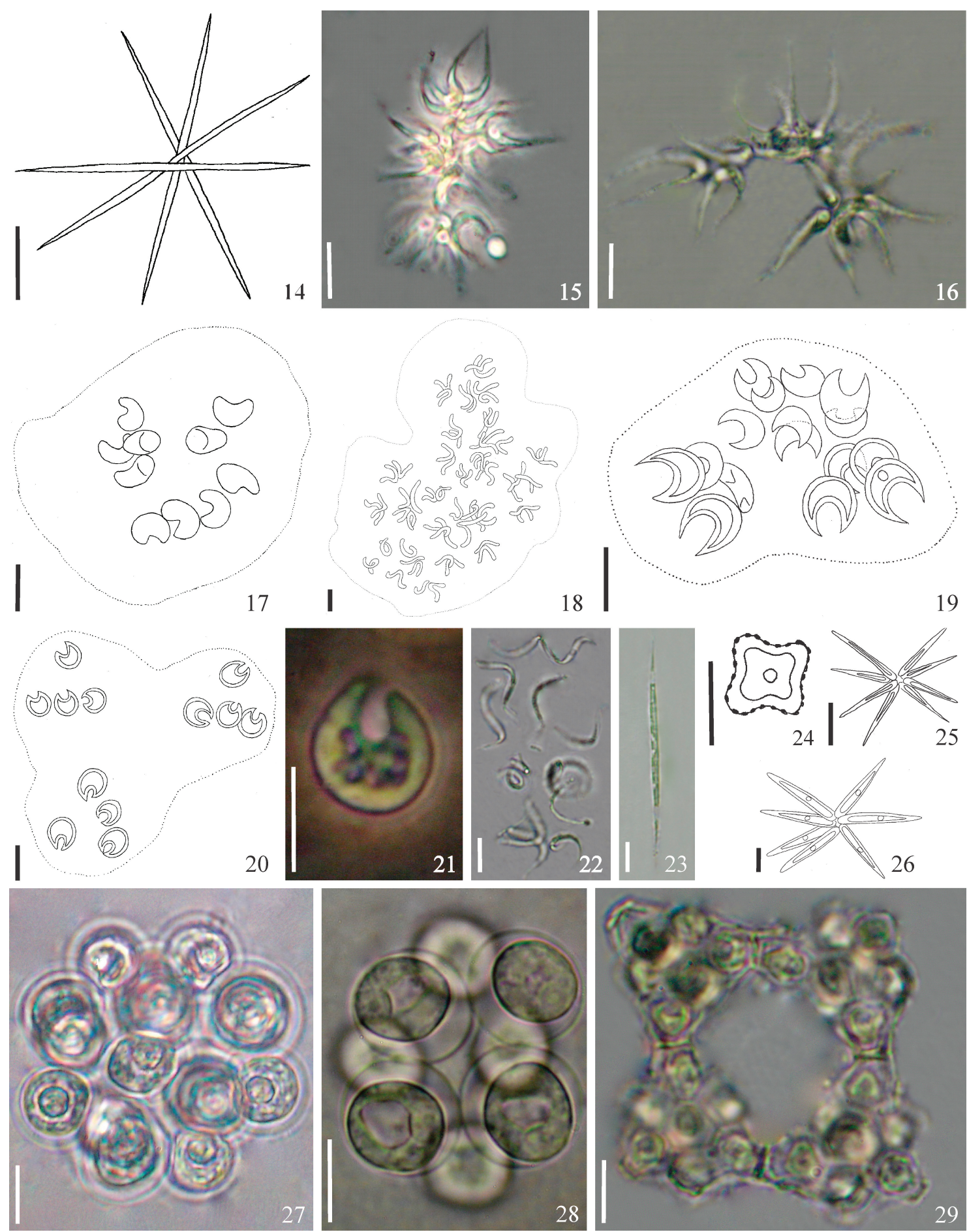

Figuras 14-29. Espécies de Chlorococcales de pesqueiros da Região Metropolitana de São Paulo. 14. Ankistrodesmus fusiformis. 15-16. A. gracilis. 15. Contraste de fase. 17. Kirchneriella aperta. 18. K. contorta var. elongata. 19. K. dianae. 20-21. K. lunaris. 21. Abertura entre os ápices em forma de "O". 22. Monoraphidium contortum. 23. M. griffithii. 24. Tetraëdron minimum. 25. Actinastrum aciculare var. aciculare f. minimum. 26. A. hantzschii var. subtile. 27. Coelastrum microporum. 28. C. microporum var. octaedricum. 29. C. prosbocideum. Barras das escalas $=10 \mu \mathrm{m}$.

Figures 14-29. Chlorococcales species found on fishing ponds in the Metropolitan Region of São Paulo. 14. Ankistrodesmus fusiformis. 15-16. A. gracilis. 15. Phase contrast. 17. Kirchneriella aperta. 18. K. contorta var. elongata. 19. K. dianae. 20-21. K. lunaris. 21. Opening between the O-shaped apexes. 22. Monoraphidium contortum. 23. M. griffithii. 24. Tetraëdron minimum. 25. Actinastrum aciculare var. aciculare f. minimum. 26. A. hantzschii var. subtile. 27. Coelastrum microporum. 28. C. microporum var. octaedricum. 29. C. prosbocideum. Scale bars $=10 \mu \mathrm{m}$. 
união, raramente dois, e pela frequente ocorrência de sincenóbios (Komárek \& Fott 1983, Nogueira 1991, Comas 1996, Tell 2001).

Segundo Nogueira (1991), C. reticulatum assemelha-se a C. polychordum (Koršikov) var. polychordum Hindák do qual difere pela presença de dois a três processos de união entre as células neste último táxon. Sant'Anna (1984) encontrou indivíduos com características tanto de $C$. reticulatum, quanto de $C$. polycordum, no entanto, por não considerar o número de ligações entre as células vizinhas uma característica suficientemente distintiva, nem mesmo no nível de variedade, identificou os dois morfotipos como C. reticulatum. Comas (1989) descreveu Coelastrum reticulatum var. duplex como uma forma de transição entre $C$. reticulatum e $C$. polychordum caracterizando-a pela presença de dois processos de união entre as células vizinhas, raramente 1 e 3 .

Em meio às populações analisadas, foram registrados indivíduos com características de C. polycordum, todos em autoesporulação (figura 36). Indivíduos semelhantes a estes foram identificados por Treviño (2008) como Hariotina reticulata. Recentemente, Hegewald et al. (2002) restabeleceram o gênero Hariotina e incluiu C. polycordum em Hariotina reticulata. Segundo estes autores, as células das espécies de Coelastrum são conectadas subbasalmente com ou sem prolongamentos da parede celular, enquanto em Hariotina as células são conectadas apicalmente por fios de ligação da camada exterior da parede celular; além disso, segundo estes mesmos autores, as células das espécies de Hariotina estão embebidas em ampla mucilagem, que em Coelastrum não é desenvolvida. No entanto, os diferentes morfotipos observados foram identificados como C. reticulatum, concordando com Sant'Anna (1984).

\section{HYDRODICTYACEAE}

\section{Monactinus Corda in Corda, A.J.C. 1839}

Monactinus simplex (Meyen) Corda, Alm. Carlsbad 9: 239. $1839 \equiv$ Pediastrum simplex Meyen, Nova Acta Acad. Caesar. Leop. Carol. 14: 772.1829. Figuras 38-39

Cenóbios circulares, planos, formados por 8-16-32 células dispostas concentricamente, com espaços intercelulares presentes; células externas poligonais com 1 processo cilíndrico cônico de ápice truncado, 12,1-37,0 $\mu \mathrm{m}$ compr., 7,2-20,0 $\mu \mathrm{m}$ diâm.; células internas poligonais, 6,8-20,0 $\mu \mathrm{m}$ compr., 6,0-19,0 $\mu \mathrm{m}$ diâm.; cloroplasto único parietal, estendendo por todo o processo, 1 pirenóide central.

Material examinado: BRASIL. São Paulo: São Paulo, Pesqueiro 8, 21-II-2002, K.E. Esteves s.n. (SP391348); Pesqueiro 10, 26-II-2002, K.E. Esteves s.n. (SP400154); Pesqueiro 11, 26-II-2002, K.E. Esteves s.n. (SP391350); Pesqueiro 14, 24-IX-2001, K.E. Esteves s.n. (SP400161); idem, 28-II-2002, K.E. Esteves s.n. (SP391352); Pesqueiro 16, 25-IX-2001, K.E. Esteves s.n. (SP400156); Pesqueiro 18, 10-X-2001, K.E. Esteves s.n. (SP400160); Pesqueiro 25, 8-X-2001, K.E. Esteves s.n. (SP400153); Pesqueiro 27, 10-X-2001, K.E. Esteves s.n. (SP400155); idem, 19-III-2002, K.E. Esteves s.n. (SP391358); Pesqueiro 30, 10-X-2001, K.E. Esteves s.n. (SP400157); idem, 19-III-2002, K.E. Esteves s.n. (SP400158).

Em 1839 Corda havia considerado P. simplex uma espécie diferente das de Pediastrum e propôs o gênero Monactinus para acomodar esta espécie. Buchheim et al. (2005) mostraram que essa particularidade comprova-se também em análises moleculares, onde Pediatrum simplex forma uma linhagem separada do clado Pediastrum. Diante disso, Buchheim et al. (2005) restabeleceram o gênero proposto por Corda (1839).

Segundo Comas (1996), esta epécie possui ampla variabilidade morfológica nas formas celulares, nos cenóbios que ora se apresentam perfurados ora não, além das ornamentações nas paredes celulares que variam desde lisas até verrugosas. Devido a isto, diferentes variedades e formas taxonômicas foram descritas. No entanto, Komárek \& Fott (1983) comentaram que é difícil separar esses táxons, uma vez que não apresentam clara distinção entre si; somente duas variedades são bem definidas e diferenciam-se pelas ornamentações na parede celular. Grânulos grosseiros nas paredes celulares seriam características da var. simplex, enquanto que granulação muito fina com paredes celulares quase lisas seriam características da var. clathratum. As populações analisadas apresentaram dois morfotipos: indivíduos com células poligonais, as externas não pareadas, cenóbios perfurados e parede celular lisa (figura 39); indivíduos com células externas pareadas, com as bases por onde se unem as células vizinhas, mais curtas e as projeções de ambas as células orientando-se mais ou menos paralelamente (figura 38), estes indivíduos são 
semelhantes ao ilustrado por Komárek \& Fott (1983) e descrito e ilustrado por Comas (1996) como P. simplex var. biwaense. Entretanto esse autor comenta que a var. biwaense não foi validamente publicada. Assim, diante deste problema nomenclatural, estes indivíduos com características de P. simplex var. biwaense foram identificados como $M$. simplex var. simplex.

Pediastrum Meyen 1829

Chave para identificação das espécies de Pediastrum em pesqueiros da RMSP

1. Células marginais com processsos levemente cônicos, curtos e alargados

1. Células marginais com processos P. duplex var. duplex cilíndricos, alongados e estreitos. P. duplex var. gracillimum

Pediastrum duplex var. duplex Meyen, Nova Acta Acad. Caesar. Leop. Carol. 14: 772. 1829.

Figuras 40-41

Cenóbios circulares, planos, formados por 16-32 células dispostas concentricamente, com espaços intercelulares presentes; células externas poligonais com 2 processos cônicos cilíndricos com ápices truncados, 8,1-14,5 $\mu \mathrm{m}$ compr., 7,0-12,1 $\mu \mathrm{m}$ diâm.; células unidas entre si pelas bases; células internas retangulares ou em forma de " $\mathrm{H}$ "; cloroplasto único parietal, estendendo por todo o processo, com 1 pirenóide central.

Material examinado: BRASIL. São PaUlo: São Paulo, Pesqueiro 8, 17-IX-2001, K.E. Esteves s.n. (SP400164); idem, 21-II-2002, K.E. Esteves s.n. (SP391348); Pesqueiro 9, 17-IX-2001, K.E. Esteves s.n. (SP400163); idem, 21-II-2002, K.E. Esteves s.n. (SP391349); Pesqueiro 10, 19-IX-2001, K.E. Esteves s.n. (SP400159); idem, 26-II-2002, K.E. Esteves s.n. (SP400154); Pesqueiro 18, 10-X-2001, K.E. Esteves s.n. (SP400160); Pesqueiro 25, 8-X-2001, K.E. Esteves s.n. (SP400153); idem, 21-III-2002, K.E. Esteves s.n. (SP391357); Pesqueiro 27, 10-X-2001, K.E. Esteves s.n. (SP400155); Pesqueiro 30, 19-III-2002, K.E. Esteves s.n. (SP400158).

Com base em análises moleculares dos genes $18 \mathrm{~S}$ e 26S, Buchheim et al. (2005) demonstraram que o gênero Pediastrum não é monofilético. Assim, dividiram-no em cinco gêneros independentes: Pediastrum, com o clado que contém a espécie-tipo Pediastrum duplex; Monactinus (Corda) Hegewald, que foi restabelecido para abrigar os indivíduos identificados como Pediastrum simplex; Stauridium Corda, que foi restabelecido para abrigar os indivíduos identificados como Pediastrum privum (Printz) Hegewald e P. tetras; Parapediastrum E. Hegewald e Pseudopediastrum E. Hegewald, que foram descritos para acomodar Pediastrum biradiatum Meyen, P. longicornutum (Gutwinski) A. Comas no primeiro e Pediastrum boryanum (Turpin) Meneghini e P. kawraiskyi Schmidle no último.

Segundo Komárek \& Fott (1983), Pediastrum duplex var. duplex apresenta parede celular lisa ou com alguns grânulos finos, irregularmente distribuídos nas células. Quando indivíduos de P. duplex var. duplex apresentam esses grânulos nas células podem ser facilmente confundidos com os da var. subgranulatum, no entanto, nesta variedade, segundo Komárek \& Fott (1983), a granulação é fina, regular e densa. As populações analisadas apresentaram indivíduos com parede celular lisa e indivíduos com parede celular com alguns grânulos finos e irregularmente distribuídos concordando com o descrito por Komárek \& Fott (1983).

Pediastrum duplex var. gracillimum W. West \& G.S. West, J. Bot. 33: 52. 1895.

Figura 42-43

Cenóbios circulares, planos, formados por 8-16-32 células dispostas concentricamente, com espaços intercelulares presentes; células externas poligonais, com 2 processos cilíndricos com ápices truncados, 12,1-19,5 $\mu \mathrm{m}$ compr., 10,5-17,1 $\mu$ m diâm.; células unidas entre si pelas bases; células internas em forma retangulares de " $\mathrm{H}$ "; cloroplasto único parietal estendendo por todo o processo, com 1 pirenóide central.

Material examinado: BRASIL. São PAULo: São Paulo, Pesqueiro 8, 17-IX-2001, K.E. Esteves s.n. (SP400164); idem, 21-II-2002, K.E. Esteves s.n. (SP391348); Pesqueiro 9, 17-IX-2001, K.E. Esteves s.n. (SP400163); idem, 21-II-2002, K.E. Esteves s.n. (SP391349); Pesqueiro 10, 19-IX-2001, K.E. Esteves s.n. (SP400159); Pesqueiro 18, 19-III-2002, K.E. Esteves s.n. (SP391359); Pesqueiro 25, 8-X-2001, K.E. Esteves s.n. (SP400153); idem, 21-III-2002, K.E. Esteves s.n. (SP391357); Pesqueiro 27, 10-X-2001, K.E. Esteves s.n. (SP400155); idem, 19-III-2002, K.E. Esteves s.n. (SP391358); Pesqueiro 30, 10-X-2001, K.E. Esteves s.n. (SP400157); idem, 19-III-2002, K.E. Esteves s.n. (SP400158). 
Pediastrum duplex var. gracillimum difere da variedade típica da espécie pela forma das células (tabela 5). Pediastrum duplex var. gracillimum apresenta células marginais com processos cilíndricos, alongados e estreitos e células centrais com as mesmas características, enquanto que $P$. duplex var. duplex apresenta células marginais com processsos levemente cônicos, curtos e alargados. As populações analisadas concordam com o material descrito por Komárek \& Fott (1983).

\section{Stauridium Corda 1839}

Stauridium tetras (Ehrenberg) Hegewald, J. Phycol. 41: 1051. 2005 三 Micrasterias tetras Ehrenberg, Infusionsthierchen 1:155. 1838.

Figuras 44-46

Cenóbios circulares ou quadráticos, planos, formados por 4-8-16 células dispostas concentricamente, espaços intercelulares ausentes, células periféricas poligonais, 7,2-13,0 $\mu \mathrm{m}$ compr., 5,6-11,0 $\mu \mathrm{m}$ diâm., margens externas com uma incisão mediana em forma de "U" resultando em dois processos curtos; células internas poligonais, 5-8 lados com incisão mediana em forma de "U"; cloroplasto único parietal; 1 pirenóide.

Material examinado: BRASIL. São PAUlo: São Paulo, Pesqueiro 8, 17-IX-2001, K.E. Esteves s.n. (SP400164); Pesqueiro 9, 21-II-2002, K.E. Esteves s.n. (SP391349); Pesqueiro 10, 19-IX-2001, K.E. Esteves s.n. (SP400159); idem, 26-II-2002, K.E. Esteves s.n. (SP400154); Pesqueiro 14, 28-II-2002, K.E. Esteves s.n. (SP391352); Pesqueiro 25, 21-III-2002, K.E. Esteves s.n. (SP391357); idem, 21-III-2002, K.E. Esteves s.n. (SP391357); Pesqueiro 27, 10-X-2001, K.E. Esteves s.n. (SP400155); Pesqueiro 30, 10-X-2001, K.E. Esteves S.n. (SP400157); idem, 19-III-2002, K.E. Esteves s.n. (SP400158).

Pediastrum tetras (Ehrenberg) Ralfs e Pediastrum privum (Printz) Hegewald foram segundo análises moleculares, transferidos para o gênero Stauridium estabelecido para acomodar estas espécies (Buchheim et al. 2005).

\section{MICRACTINIACEAE}

\section{Micractinium Fresenius 1858}

Chave para identificação das espécies de Micractinium em pesqueiros a RMSP

1. Colônias piramidais M. borhemiense

1. Colônias quadráticas M. pusillum
Micractinium borhemiense (Conrad) Koršikov, Protococcineae 4011953 E Errerella bornhemiensis Conrad, Bull. Soc. Bot. Belg. 52: 242. 1913. Figura 47

Colônias piramidais, formadas por 16 células esféricas, 5,6 $\mu \mathrm{m}$ de diâm.; células com espinhos retos, hialinos, delicados, distribuídos na parede celular, 22,6 $\mu \mathrm{m}$ de compr.; cloroplasto único, poculiforme, com 1 pirenóide.

Material examinado: BRASIL. São Paulo: Pesqueiro 30, 10-X-2001, K.E. Esteves s.n. (SP400157); idem, 19-III-2002, K.E. Esteves s.n. (SP400158).

Micractinium borhemiense assemelha-se a Micractinium pusillum Fresenius mas, segundo Komárek \& Fott (1983), M. borhemiense apresenta colônias piramidais e 1 espinho por célula, enquanto M. pusillum apresenta colônias tetraédricas e 2-13 espinhos por célula. Outros autores mencionaram e ilustraram 1-5 espinhos por célula em $M$. borhemiense (Sant'Anna 1984, Sant'Anna et al. 1989 e Rodrigues 2008). Philiphose (1967) comentou que o número de espinhos não pode ser levado em conta, pois é um carácter bastante variável. Luo et al. (2006) mencionou que a formação de espinhos representa adaptação fenotípica para as condições ambientais. Nos indivíduos analisados não foi possível definir com precisão o número de espinhos por serem hialinos e delicados, mesmo observando o material em contraste de fase.

Micractinium pusillum Fresenius, Abh. Senckenb.

Natforsch. Ges. 2: 236. 1858.

Figuras 48

Colônias quadráticas, formadas por 4-8-16 células esféricas, 4,0-7,2 $\mu$ m diâm.; células com 3-4 espinhos retos, hialinos, dispostos na parede celular, 16,2-40,5 $\mu \mathrm{m}$ compr.; cloroplasto único, poculiforme, com 1 pirenóide.

Material examinado: BRASIL. São PAULo: São Paulo, Pesqueiro 8, 21-II-2002, K.E. Esteves s.n. (SP391348); Pesqueiro 10, 19-IX-2001, K.E. Esteves s.n. (SP400159); idem, 26-II-2002, K.E. Esteves s.n. (SP400154); Pesqueiro 11, 26-II-2002, K.E. Esteves s.n. (SP391350); Pesqueiro 18, 10-X-2001, K.E. Esteves s.n. (SP400160); Pesqueiro 25, 8-X-2001, K.E. Esteves s.n. (SP400153); Pesqueiro 30, 10-X-2001, K.E. Esteves s.n. (SP400157).

As populações analisadas concordam com o material descrito por Nogueira (1991). 

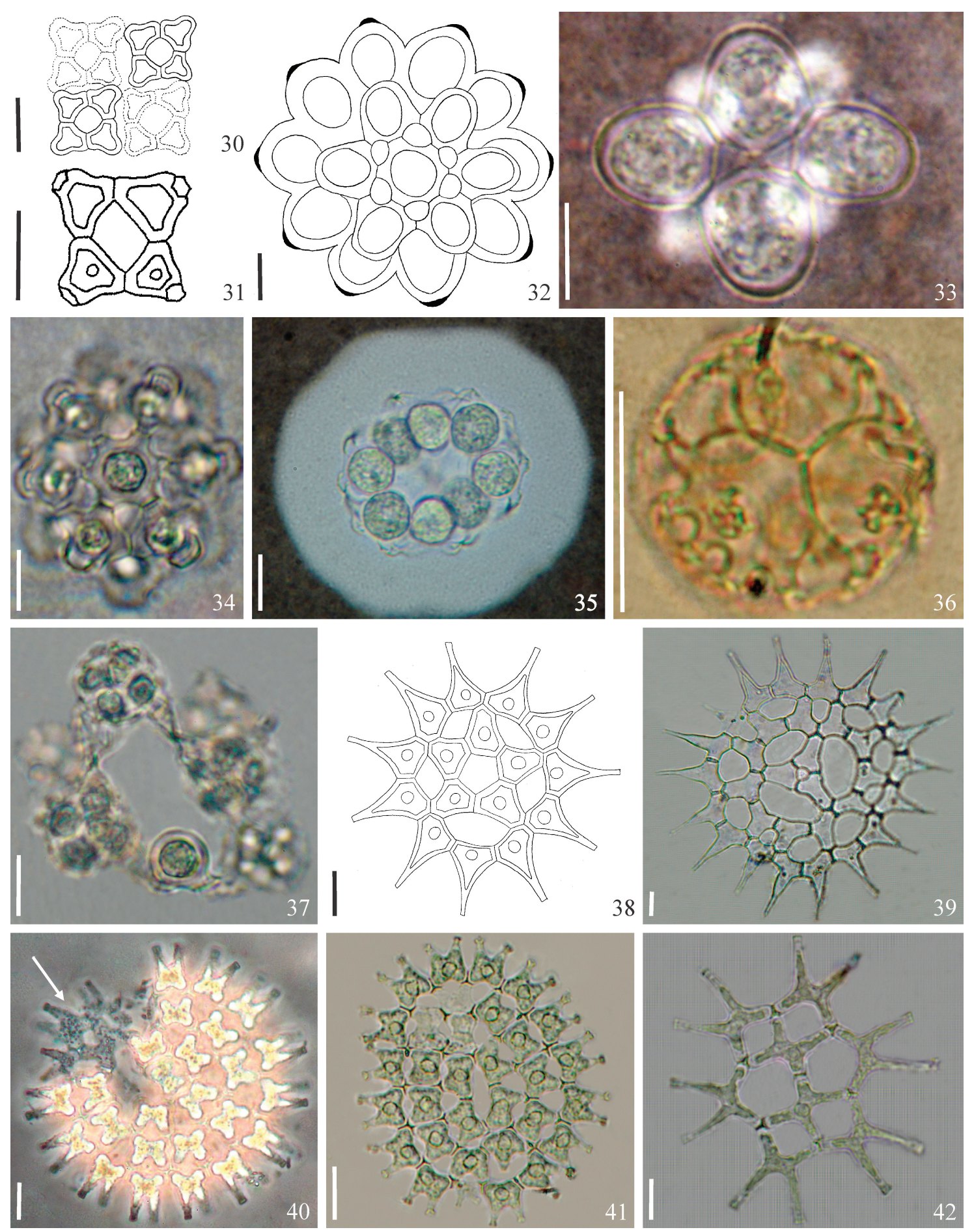

Figuras 30-42. Espécies de Chlorococcales de pesqueiros da Região Metropolitana de São Paulo. 30-31. Coelastrum prosbocideum. 32-33. Coelastrum pseudomicroporum. 34. Coelastrum pulchrum. 35-37. Coelastrum reticulatum. 36. Célula em autoesporulação, com dois a três processos de união entre as células vizinhas. 37. Colônias típicas em autoesporulação. 38-39. Monactinus simples. 38. Colônias com células externas pareadas. 40-41. Pediastrum duplex var. duplex. 40. Detalhe da parede celular finamente granulada. 42. Pediastrum duplex var. gracillimum. Barras de escalas $=10 \mu \mathrm{m}$.

Figures 30-42. Chlorococcales species found on fishing ponds in the Metropolitan Region of São Paulo. 30-31. Coelastrum prosbocideum. 32-33. Coelastrum pseudomicroporum. 34. Coelastrum pulchrum. 35-37. Coelastrum reticulatum. 36. Self-sporulating cell, with two to three processes of union between neighboring cells. 37. Typical self-sporulating colonies. 38-39. Monactinus simples. 38. Colonies with paired outer cells. 40-41. Pediastrum duplex var. duplex. 40. Detail of the finely granulated cell wall. 42. Pediastrum duplex var. gracillimum. Scale bars $=10 \mu \mathrm{m}$. 
Tabela 5. Diferenças morfológicas das células de Pediastrum duplex var. duplex e P. duplex var. gracillimum (modificado de Komárek \& Fott 1983), Região Metropolitana de São Paulo, Brasil.

Table 5. Morphological differences between cells of Pediastrum duplex var. duplex and P. duplex var. gracillimum (modified Komárek \& Fott 1983), Metropolitan Region of São Paulo, Brazil.

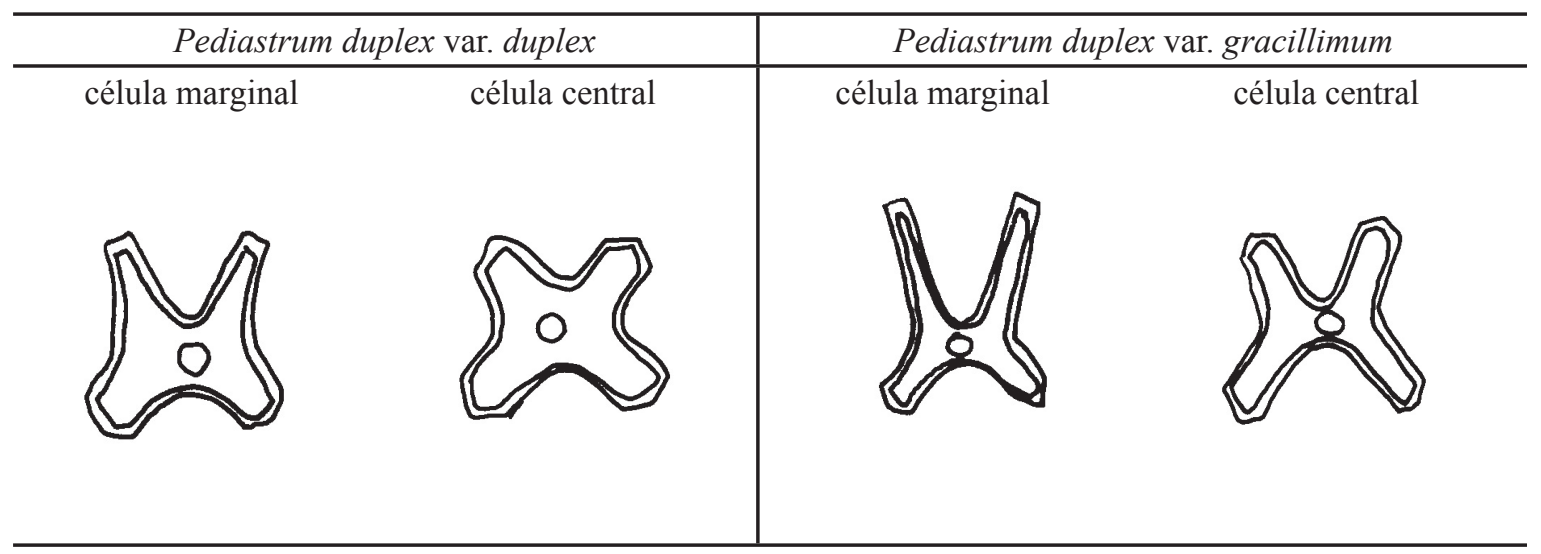

\section{OOCYSTACEAE}

Franceia Lemmermann 1898

Franceia cf. droescheri (Lemmermann) G.M.Smith, Freshwater algae of the United States: $505.1933 \equiv$ Chodatella droescheri Lemmermann, Ber. Dtsch. Bot. Ges. 18: 98. 1900.

Figuras 49-52

Células isoladas, quase esféricas, 13,0-20, $2 \mu \mathrm{m}$ compr., 11,0-16,2 Hm diâm., 16-22 espinhos, delicados, levemente espessados na base, 32-52,6 $\mu \mathrm{m}$ compr., levemente curvados; 2 cloroplastos parietais; 1 pirenóide por cloroplasto; reprodução por 4-8 autósporos, que permanecem no interior da célula mãe alargada, até a sua liberação, que ocorre por rompimento da parede celular materna.

Material examinado: BRASIL. São PAULo: São Paulo, Pesqueiro 8, 21-II-2002, K.E. Esteves s.n. (SP391348); Pesqueiro 10, 19-IX-2001, K.E. Esteves s.n. (SP400159); idem, 26-II-2002, K.E. Esteves s.n. (SP400154); Pesqueiro 14, 24-IX-2001, K.E. Esteves s.n. (SP400161); idem, 28-II-2002, K.E. Esteves s.n. (SP391352); Pesqueiro 18, 19-III-2002, K.E. Esteves s.n. (SP391359).

Dentre as 12 espécies descritas por Komárek \& Fott (1983), a população analisada assemelha-se a $F$. aranea (Behre) Fott e a $F$. droescheri pela forma da célula, mas difere de ambas pelo número e tamanho dos espinhos. Franceia aranea é descrita contendo 12 espinhos de 50-75 $\mu$ m compr., e F. droescheri possui acima de 30 espinhos com 9-22 (32) $\mu \mathrm{m}$ de compr.
Embora a população estudada tenha apresentado número de espinhos menores que em $F$. droescherii, a mesma foi considerada como esta espécie, pois segundo Luo et al. (2006), a formação e o número de espinhos representam adaptações às condições ambientais. Além disso, Rodrigues (2008) descreveu e ilustrou populações semelhantes às populações analisadas, diferindo apenas pelo número de espinhos (22-25).

Nas populações dos pesqueiros estudados, vários indivíduos foram registrados em auto-esporulação, com células mãe esféricas, com 26,0-35,0 $\mu \mathrm{m}$ de diâmetro.

\section{Lagerheimia Chodat 1895}

Lagerheimia ciliata (Lagerheim) R. Chodat, Nuova Notarisia 4: 90. 1895 Eocystis ciliata Lagerheim, Bih. K. svenska Vetenskakad. Handl. 39: 76, pl. 3, fig. 33-37. 1882.

Figuras 53-56

Células isoladas, elípticas, 12,1-16,2 $\mu \mathrm{m}$ compr., 7,5-12,1 $\mu \mathrm{m}$ diâm.; 5-7 espinhos polares, curvos, 17,8-32,4 $\mu \mathrm{m}$ compr.; cloroplasto parietal único; com pirenóide conspícuo.

Material examinado: BRASIL. São PAulo: São Paulo, Pesqueiro 14, 24-IX-2001, K.E. Esteves s.n. (SP400161); Pesqueiro 16, 25-IX-2001, K.E. Esteves s.n. (SP400156); Pesqueiro 25, 8-X-2001, K.E. Esteves s.n. (SP400153); idem, 21-III-2002, K.E. Esteves s.n. (SP391357); Pesqueiro 30, 10-X-2001, K.E. Esteves s.n. (SP400157); Pesqueiro 30, 19-III-2002, K.E. Esteves s.n. (SP400158). 
Lagerheimia ciliata é morfologicamente semelhante à Lagerheimia longiseta (Lemmermann) Wille, da qual difere pela presença de espinhos maiores, acima de $40 \mu \mathrm{m}$ compr. (Komárek \& Fott 1983). As populações analisadas apresentaram grande variação na forma da célula e no tamanho dos espinhos, desde células oblongas com espinhos longos (20-25 $\mu \mathrm{m}$ compr.) até células elipsoidais com espinhos ora curtos (8,0-12,0 $\mu \mathrm{m}$ compr.), ora longos (25,0 $\mu \mathrm{m}$ compr.). Foram observados muitos indivíduos em autoesporulação, alguns com células citriformes e cloroplastos em divisão com 1 pirenóide conspícuo cada. A maioria dos indivíduos analisados apresentou forma da célula oblonga, com

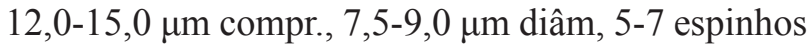
polares com 20-25 $\mu \mathrm{m}$ de comprimento, retos a levemente curvos, concordando com o descrito por Komárek \& Fott (1983).

\section{Oocystis Nägeli 1855}

Chave para identificação das espécies de Oocystis encontradas em pesqueiros da RMSP

1. Células ovóides a oblongas O. borgei

1. Células elípticas

2. Células com $\mathrm{Rc} / \mathrm{l}=2$ O.lacustris

2. Células com $\mathrm{Rc} / 1<2$ O.marssonii

Oocystis borgei J. Snow, Bull. U.S. Fish Comm. 22: 379. 1903.

Figuras 57-59

Colônias com 2-4-8 células irregularmente distribuídas em mucilagem; células ovóides a

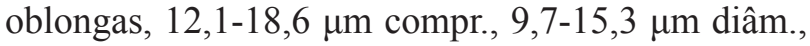
pólos arredondados, espessamentos polares ausentes; 2-4 cloroplastos poculiformes com 1 pirenóide cada.

Material examinado: BRASIL. São PAUlo: São Paulo, Pesqueiro 8, 17-IX-2001, K.E. Esteves s.n. (SP400164); idem, 21-II-2002, K.E. Esteves s.n. (SP391348); Pesqueiro 9, 17-IX-2001, K.E. Esteves s.n. (SP400163); idem, 21-II-2002, K.E. Esteves s.n. (SP391349); Pesqueiro 10, 26-II-2002, K.E. Esteves s.n. (SP400154); Pesqueiro 11, 26-II-2002, K.E. Esteves s.n. (SP391350); Pesqueiro 14, 24-IX-2001, K.E. Esteves s.n. (SP400161); Pesqueiro 25, 8-X-2001, K.E. Esteves s.n. (SP400153); Pesqueiro 27, 10-X-2001, K.E. Esteves s.n. (SP400155); Pesqueiro 30, 10-X-2001, K.E. Esteves s.n. (SP400157); idem, 19-III-2002, K.E. Esteves s.n. (SP400158).
Oocystis lacustris R. Chodat, Bull. Herb. Boissier 5. 119, pl. 10, fig 1-7. 1897.

Figura 60

Colônias formadas por 4 células irregularmente dispostas em mucilagem; células elípticas,

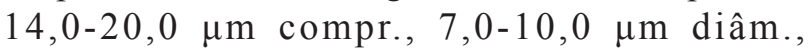
$\mathrm{Rc} / 1=1,9-2,0$; pólos agudos, espessamentos polares ausentes; 4 cloroplastos parietais, poligonais, pirenóide não observado.

Material examinado: BRASIL. São PAULO: São Paulo, Pesqueiro 11, 26-II-2002, K.E. Esteves s.n. (SP391350); Pesqueiro 14, 24-IX-2001, K.E. Esteves s.n. (SP400161); idem, 28-II-2002, K.E. Esteves s.n. (SP391352).

Os indivíduos identificados como $O$. lacustris concordam com os materiais descritos por Reháková (1969), Komárek \& Fott (1983) e Comas (1996).

Oocystis marssonii Lemmermann, Bot. Centralbl. 76: 151.1898.

Figuras 61-62

Colônias com 4-8 células irregularmente dispostas em mucilagem; células elípticas, 12,9-20,0 $\mu \mathrm{m}$ compr., 10,5-15,0 $\mu \mathrm{m}$ diâm., Rc/1 abaixo de 2; pólos levemente agudos, espessamento polar não observado; 2-4 cloroplastos com 1 pirenóide cada.

Material examinado: BRASIL. São PAUlo: São Paulo, Pesqueiro 8, 21-II-2002, K.E. Esteves s.n. (SP391348); Pesqueiro 9, 17-IX-2001, K.E. Esteves s.n. (SP400163); idem, 21-II-2002, K.E. Esteves s.n. (SP391349); Pesqueiro 10, 19-IX-2001, K.E. Esteves s.n. (SP400159); Pesqueiro 11, 19-IX-2001, K.E. Esteves s.n. (SP400162); idem, 26-II-2002, K.E.Estevess.n. (SP391350); Pesqueiro 14, 24-IX-2001, K.E. Esteves s.n. (SP400161); Pesqueiro 25, 21-III2002, K.E. Esteves s.n. (SP391357); Pesqueiro 27, 10-X-2001, K.E. Esteves s.n. (SP400155); idem, 19-III-2002, K.E. Esteves s.n. (SP391358); Pesqueiro 30, 10-X-2001, K.E. Esteves s.n. (SP400157); idem, 19-III-2002, K.E. Esteves s.n. (SP400158).

Reháková (1969) distingue O. marssonii de O. lacustris, principalmente pelo número de cloroplastos nas células jovens, pela razão comprimento/largura (Rc/l) das células e pelas forma de liberação dos autósporos da parede da célula-mãe. Oocystis marssonii apresenta 2 cloroplastos nas células jovens, Rc/l abaixo de 1,3 e os autósporos são liberados por ruptura da parede da célula mãe, enquanto 

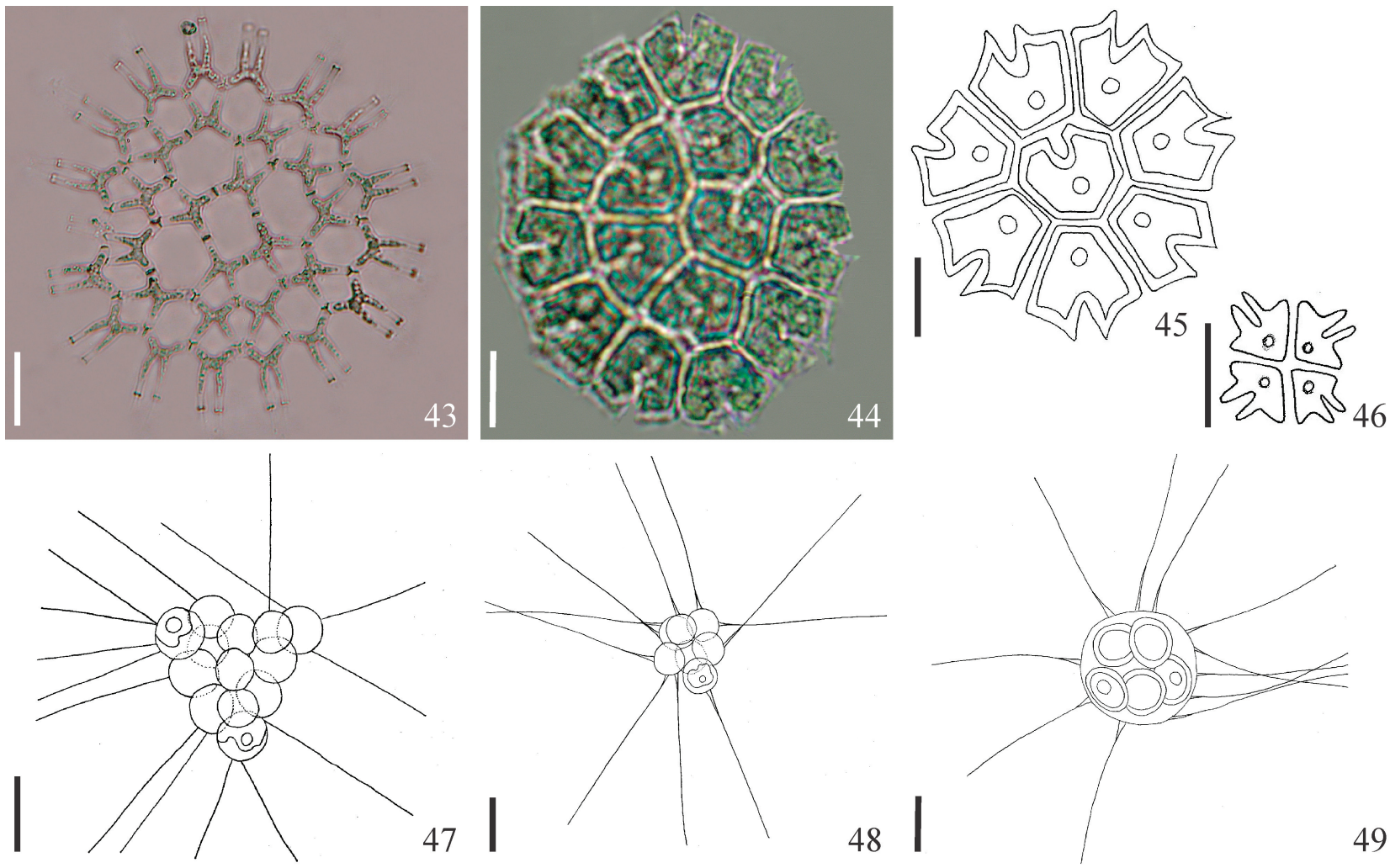

49
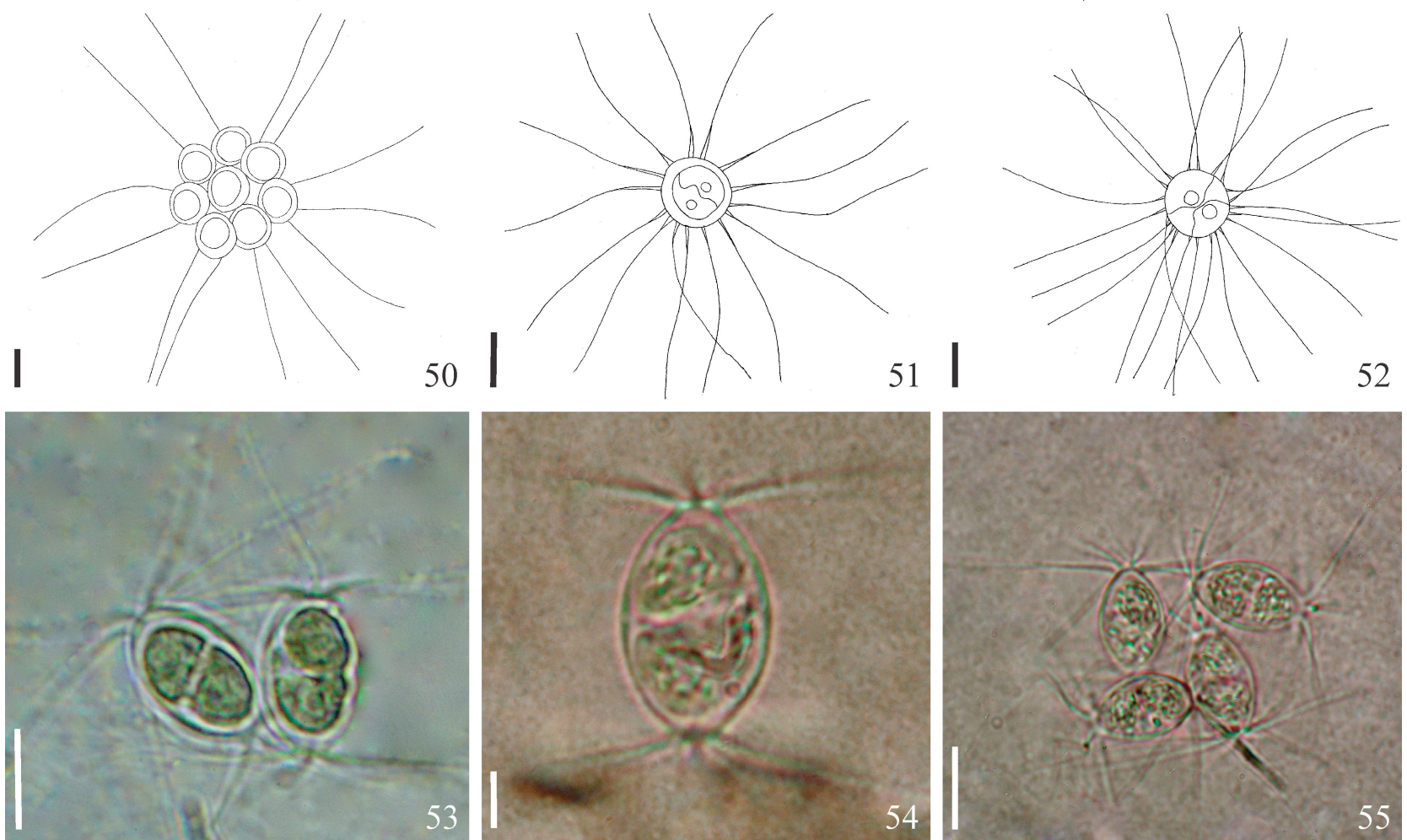

Figuras 43-55. Espécies de Chlorococcales de pesqueiros da Região Metropolitana de São Paulo. 43. Pediastrum duplex var. gracillimum. 44-46. Stauridium tetras. 47. Micractinium borhemiense. 48. Micractinium pusillum. 49-52. Franceia cf. droescheri. 49. Indivíduos em autoesporulação. 51-52. Variação no número de espinhos. 53-55. Lagerheimia ciliata. Barras das escalas $=10 \mu \mathrm{m}$.

Figures 43-55. Chlorococcales species found in the fishing ponds in the Metropolitan Region of São Paulo. 43. Pediastrum duplex var. gracillimum. 44-46. Stauridium tetras. 47. Micractinium borhemiense. 48. Micractinium pusillum. 49-52. Franceia cf. droescheri. 49. Self-sporulating individuals. 51-52. Variation in the number of spines. 53-55. Lagerheimia ciliata. Scale bars $=10 \mu \mathrm{m}$. 
O. lacustris apresenta 1 cloroplasto, razão Rc/1 acima de 1,9 e autóporos liberados por gelatinizaçào da parede da célula mãe. Komárek \& Fott (1983) as distinguem também, além do número de cloroplastos nas células jovens, pelas dimensões celulares, 6,4-25-(32) × 4-14-(22?) $\mu \mathrm{m}$ em O. marssonii, (4)-6,4-11,2-(14,4) × (1,6)-3,2-6,4-(10) $\mu \mathrm{m} \mathrm{em}$ $O$. lacustris e adiciona a $O$. lacustris a possibilidade da formação de colônias com células de diferentes gerações. O material analisado foi identificado como O. marssonii, por apresentar dimensões celulares e Rc/1 que concordam com a descrição de Komárek \& Fott (1983).

\section{Tetrachlorella Koršikov 1939}

Tetrachlorella alternans (G.M. Smith) Koršikov, Uchenye Zapiski Gorkovskogo gosudarstvennogo universiteta 9: 116, 126. 1939 ECrucigenia alternans G.M. Smith, Transactions of the American Microscopical Society 45: 185, pl. 14, fig. 14-18.1926.

Figura 63

Cenóbios formados por 4 células dispostas alternadamente; células oblongas, 11,5-15,3 $\mu \mathrm{m}$ compr., 5,0-5,6 $\mu \mathrm{m}$ diâm., não totalmente unidas entre si; parede celular lisa; 1 ou 2 cloroplatos parietais; 1 pirenóide.

Este gênero pertencia a Scenedesmaceae, no entanto, Hepperle et al. (2000) comprovaram através de análises moleculares que Tetrachlorellla alternans pertence a Oocystaceae. Segundo Comas (1996) as espécies de Tetrachlorella assemelham-se às de Oocystis no que diz respeito à reprodução, pois em Oocystis os autósporos são liberados pela gelatinização da parede da célula mãe. No entanto o arranjo característico das células no cenóbio dos representantes de Tetrachlorella os distingue dos representantes de Oocystis. Segundo Comas (1996), os cenóbios são formados por 4 células arranjadas em uma forma particular: as internas unem-se mais ou menos paralelamente ou ligeiramente convergentes, pouco inclinadas e as células externas unem-se obliquamente a ambos extremos das internas, conferindo o aspecto alternado ao cenóbio. Tetrachlorella alternas não apresentou qualquer variabilidade morfológica e o material analisado concorda com a descrição de Komárek \& Fott (1983).

\section{RADIOCOCCACEAE}

\section{Coenocystis Koršikov 1953}

Coenocystis subcylindrica Koršikov, Protococcinae 330, fig. 303. 1953.

Figura 64

Colônias arredondadas, irregulares, ou compostas de subcolônias formadas por células dispostas mais ou menos paralelamente em 1 ou 2 planos; mucilagem hialina e difluente; células elípticas a ovais, 6,4-12,1 $\mu \mathrm{m}$ compr., 3,2-5,6 $\mu \mathrm{m}$ diâm.; cloroplasto único parietal; pirenóide não observado; reprodução por 4 autósporos orientados paralelamente em 1 ou 2 planos, liberados por gelatinização da parede da célula mãe.

Material examinado: BRASIL. São PaUlo: São Paulo, Pesqueiro 25, 21-III-2002, K.E. Esteves s.n. (SP391357).

A população analisada concorda com o material descrito por Komárek \& Fott (1983), que salientaram a presença de indivíduos sem pirenóide em meio à população por eles estudada. Segundo Nogueira (1991), Coenocystis pode ser confundida com Coccomyxa Schmidle, da qual difere pela ausência de pirenóide e pelos autósporos dispostos obliquamente. Embora não tenha sido observado pirenóide nos indivíduos encontrados, a presença dos autósporos dispostos paralelamente e a permanência de restos da parede da célula-mãe em torno dos grupos de células jovens foram caracterísiticas suficientes para distinguir a espécie.

Eutetramorus Walton 1918

Eutetramorus fottii (Hindák) Komárek, Arch. Hydrobiol. Suppl. 56 (2): 249. 1979 = Coenococcus fottii Hindák, Biol. Prace 23(4): 14, pl. 2, fig.1. 1977. Figura 65

Colônias arredondadas, formadas por 8-16 células dispostas em coroa, em dois planos paralelos; mucilagem hialina e ampla; células esféricas, 4,8-7,2 $\mu \mathrm{m}$ diâm.; cloroplasto poculiforme com 1 pirenóide.

Material examinado: BRASIL. São PAUlo: São Paulo, Pesqueiro 9, 17-IX-2001, K.E. Esteves s.n. (SP400163); Pesqueiro 11, 19-IX-2001, K.E. Esteves s.n. (SP400162); Pesqueiro 14, 28-II-2002, K.E. Esteves s.n. (SP391352); Pesqueiro 30, 10-X-2001, K.E. Esteves s.n. (SP400157). 
Eutetramorus fottii caracteriza-se por apresentar colônias formadas por células dispostas em dois planos, de modo que cada célula de um dos planos localiza-se entre as duas células do outro plano, configurando colônias em forma de coroa (Nogueira 1991).

\section{TREUBARIACAE}

\section{Treubaria C. Bernard 1908}

Treubaria schmidlei (Schroder) Fott \& Kovácik, Preslia 47: 309, fig. 2a. $1975 \equiv$ Polyedrium schmidlei Schroder, Biol. Zbl. 18: 530.1898.

Figura 66
Células isoladas, triangulares, raramente tetraédricas 10-14 $\mu \mathrm{m}$ compr.; ângulos arredondados, margem levemente convexa, às vezes reta, afastadas da parede celular; 3-(4) espinhos hialinos gradualmente afilados em direção ao ápice, 24-55 $\mu \mathrm{m}$ compr.; ápices levemente arredondados; cloroplasto único parietal; 3-5 pirenóides.

Material examinado: BRASIL. São PaUlo: São Paulo, Pesqueiro 10, 19-IX-2001, K.E. Esteves s.n. (SP400159); Pesqueiro 18, 10-X-2001, K.E. Esteves s.n. (SP400160); Pesqueiro 25, 21-III-2002, K.E. Esteves s.n. (SP391357).
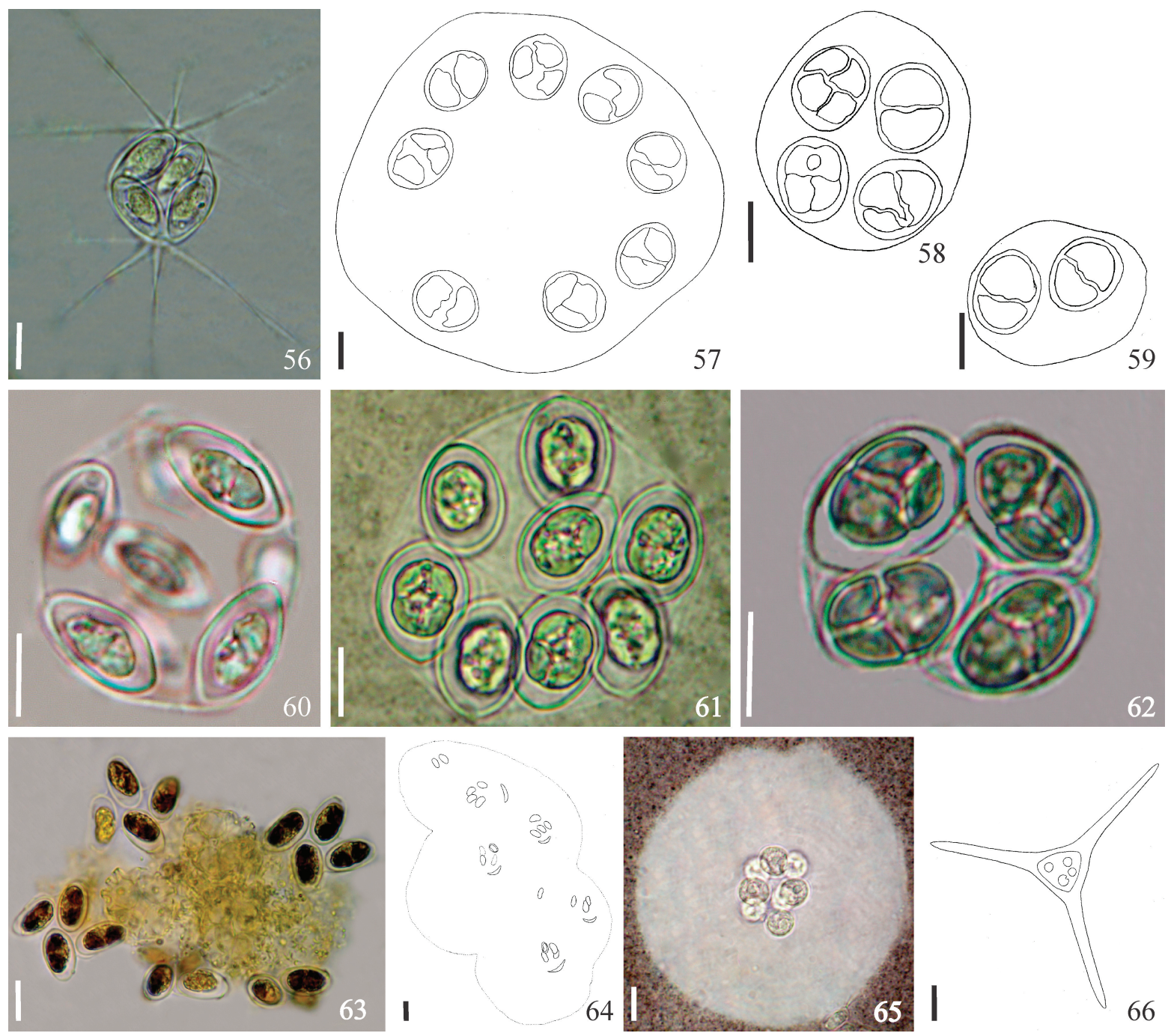

Figuras 56-66. Espécies de Chlorococcales de pesqueiros da Região Metropolitana de São Paulo. 56. Lagerheimia ciliata, indivíduos em autoesporulação. 57-59. Oocystis borgei. 60. O. lacustris. 61-62. O. marssonii. 63. Tetrachlorella alternans. 64. Coenocystis subcilindrica. 65. Eutetramorus fottii. 66. Treubaria schmidlei. Barras das escalas $=10 \mu \mathrm{m}$.

Figures 56-66. Chlorococcales species found in the fishing ponds in the Metropolitan Region of São Paulo. 56. Lagerheimia ciliata, self-sporulating individuals. 57-59. Oocystis borgei. 60. O. lacustris. 61-62. O. marssonii. 63. Tetrachlorella alternans. 64. Coenocystis subcilindrica. 65. Eutetramorus fottii. 66. Treubaria schmidlei. Scale bars $=10 \mu \mathrm{m}$. 
Treubaria schmidlei assemelha-se morfologicamente a Treubaria crassispina G.M. Smith e a T. triapendiculata Bernard, das quais difere, segundo Komárek \& Fott (1983), pelas porções basal e distal dos espinhos e pela forma do protoplasma. Em T. crassispina, os espinhos são cilíndricos na base, abruptamente afilados nas extremidades e o protoplasma justaposto à parede celular e em T. triapendiculata, os espinhos são cônicos, gradualmente afilados, com ápices pontiagudos, o protoplasma é tetraédrico ou triangualar com ângulos quase esféricos, a margem é côncava e o protoplasma é justaposto à parede celular. A população analisada não apresentou variação morfológica e concorda com o material descrito por Komárek \& Fott (1983).

Dentre os táxons identificados destacam-se também: Franceia cf. droescheri, por diferir tanto pelo número quanto pelo tamanho dos espinhos da descrição apresentada em Komárek \& Fott (1983) e, portanto, discutiu-se se essas características são suficientes para diferenciar as espécies deste gênero. Dictyosphaerium pulchellum H.C. Wood foi a única espécie com $90 \%$ de frequência de ocorrência, registrado em todos os pesqueiros, seguida por Pediastrum duplex var. gracillimum com $65 \%$ de frequência de ocorrência, Monactinus simplex e Oocystis marssonii com 60\% de frequência de ocorrência cada, considerados como constantes (tabela 2).

Apesar de terem sido realizadas duas coletas em cada sistema, uma na época de chuva e uma na seca, apenas dois táxons foram exclusivos da época de chuva: Actinastrum aciculare f. minimum e Coenocystis subcylindrica (tabela 2), indicando que a dinâmica temporal sazonal não deve ser a função de força desses sistemas, para a distinção quanto a riqueza de táxons. Estes resuldados corroboram os encontrados por Silva (2005) e Gentil (2007). As autoras comentaram que o fitoplâncton dos pesqueiros analisados de fato não responde a sazonalidade, mas sim ao manejo estabelecido pelos proprietários de pesqueiros como a abertura das comportas para permitir renovação da água, a adubação, a alimentação dos peixes e calagem dos tanques.

Dos 38 táxons identificados, 19 táxons apresentaram frequência de corrência entre 30-55\% entre os pesqueiros estudados, os quais, por sua vez, são provenientes de diferentes bacias hidrográficas (Rossini 2010). Resultados que indicam que as espécies de Chlorophyceae são amplamente distribuídas em diferentes sistemas aquáticos brasileiros, desde reservatórios a lagos rasos e urbanos, eutróficos a oligotróficos, foram registrados em Sant'Anna et al. (1989, 1997, 2006), Beyruth et al. (1998), Bicudo et al. (1999), Calijuri (1999), Henry \& Nogueira (1999), Nogueira (1999), Beyruth (2000), Huszar et al. (2000), Carvalho (2003), Tucci et al. (2004, 2006), Ferragut et al. (2005), Gentil (2007), Gentil et al. (2008), Nogueira et al. (2008), Rodrigues (2008), Granado et al. (2009), e Rosini (2010).

\section{Agradecimentos}

Ao CNPq pela concessão da bolsa de Mestrado para o primeiro autor, E.F.R.; à FAPESP processo n。 01/04081-8, pelo financiamento do projeto; a Watson Arantes Gama Junior pela confecção das pranchas; a equipe de coleta do Instituto de Pesca da Secretaria de Abastecimento de São Paulo.

\section{Literatura citada}

An, S.S., Friedel, T. \& Hegewald, E. 1999. Phylogenetic relationships of Scenedesmus and Scenedesmus-like coccoid green algae as inferred from ITS-2 rDNA sequence comparisons. Plantbiology 1: 418-428.

Beyruth, Z. 2000. Periodic disturbances, trophic gradient and phytoplankton characteristics related to cyanobacterial growth in Guarapiranga Reservoir, São Paulo State, Brazil. Hydrobiologia 424: 51-65.

Beyruth, Z., Tucci-Moura. A., Ferragut, C., Menezes, L.C.B. 1998. Caracterização e variação sazonal do fitoplâncton de tanques de aquicultura. Acta Limnologica Brasiliensia 10: 21-36.

Bicudo, C.E.M., Ramirez J.J.R., Tucci, A.N.M. \& Bicudo, D.C. 1999. Dinâmica de populações fitoplanctônicas em ambiente eutrofizado: o Lago das Garças, São Paulo. In: R. Henry (ed.). Ecologia de reservatórios: estrutura, função e aspectos sociais FUNDIBIO, Botucatu, pp. 449-508.

Branco, C.W.C. \& Senna, P.A.C. 1996. Plankton studies in Paranoá Reservoir, Brasília, Brazil. I. Relations among heterotrophic bacteria, chlorophyll $a$, total phytoplankton, total zooplankton and physichochemical factors. Hydrobiologia 337: 171-181.

Buchheim, M., Buchheim, J., Carlston, T., Braband, A., Hepperle, D., Krienitz, L. Hegewald, E. \& Wolf, M. 2005. Phylogeny of the Hydrodictyaceae (Chlorophyceae): inferences from rDNA data. Journal Phycology 41: 1039-1054.

Calijuri, M.C. 1999. A comunidade fitoplanctônica em um reservatório tropical (Barra Bonita, SP). Tese de Livre Docência, Universidade de São Paulo, São Carlos.

Carvalho, M.C. 2003. Comunidade fitoplanctônica como instrumento de biomonitoramento de reservatórios no Estado de São Paulo. Tese de Doutorado, Universidade de São Paulo, São Paulo. 
Comas, A.G. 1980. Nuevas y interesantes Chlorococcales (Chlorophyceae) de Cuba. Acta bot. Cubana 2: 1-18.

Comas, A.G. 1989. Taxonomische Übersicht der zönobialen Chlorokokkalalgen von Kuba. I. Fam. Coelastracae. Algological Studies 56: 347-364.

Comas, A.G. 1992. Taxonomische Beiträge zur Grünalgenflora (Chlorellales) aus Kubas. Algological Studies 65: 11-21.

Comas, A.G. 1996. Las Chlorococcales dulciacuícolas de Cuba. Sttutgart, Gustav Fisher Verlag.

Corda, A.J.C. 1839. Observations sur les Euastrées et les Comariées. Almanach de Carlsbad 9: 213-44.

Eler, M.N. \& Espíndola, E.L.G. 2006. Avaliação dos Impactos de Pesque-Pague: Uma Análise da Atividade na Bacia Hidrográfica do Rio Mogi-Guaçu. Rima, São Carlos.

Eler, M.N., Ceccarelli, P.S., Bufon, A.G.M. \& Espíndola, E.L.G. 2001. Mortandade de peixes (matrinxã, Brycon cephalus, e pacu, Piaractus mesopotamicus) associada a uma floração de cianobactérias em pesque-pague, município de Descalvado, Estado de São Paulo, Brasil. Boletim Técnico CEPTA 14: 35-45.

Esteves, K.E. \& Sant'Anna, C.L. 2006. Pesqueiros sob uma visão integrada de meio ambiente, saúde pública e manejo. Rima, São Paulo.

Fawley, M.W., Fawley, K.P. \& Buchheim, M.A. 2004. Molecular diversity among communities of freshwater microchlorophytes. Microbial Ecology 48: 489-499.

Ferragut, C., Lopes, M.R.M., Bicudo, D.C., Bicudo, C.E.M. \& Vercellino, I.S. 2005. Ficoflórula perifítica e planctônica (exceto Bacillariophyceae) de um reservatório oligotrófico raso (Lago do IAG, São Paulo). Hoehnea 32: 137-184.

Gentil, R.C. 2007. Estrutura e dinâmica da comunidade fitoplanctônica de pesqueiros da Região Metropolitana de São Paulo, SP, em dois períodos: seca e chuva. Tese de Doutorado, Instituto de Botânica, São Paulo.

Gentil, R.C., Tucci, A. \& Sant'Anna, C.L. 2008. Dinâmica da comunidade fitoplanctônica e aspectos sanitários de um lago urbano eutrófico em São Paulo, SP. Hoehnea 35: 265-280.

Granado, D.C., Henry, R. \& Tucci, A. 2009. Influência da variação do nível hidrométrico na comunidade fitoplanctônica do Rio Paranapanema e de uma lagoa marginal na zona de desembocadura na Represa de Jurumirim (SP). Hoehnea 36: 113-129.

Hegewald, E. Coesel, P.F.M. \& Hegewald, P. 2002. A phytoplankton collection from Bali, with the description of a new Desmodesmus species. Algological Studies 105: 57-78.

Hepperle, D., Hegewald, E. \& Krienitz, L. 2000. Phylogenetic position of the Oocystaceae (Chlorophyta). Journal of Phycology 36: 590-595.
Hindák, F. 1984. Studies on the chlorococcal algae (Chlorophyceae) III. Biologické Práce, 30, Veda, Bratislava.

Henry, R. \& Nogueira, M.G. 1999. A represa de Jurumirim (São Paulo): primeira síntese sobre o conhecimento limnológico e uma proposta preliminar de manejo ambiental. In: R. Henry (ed.). Ecologia de reservatórios: estrutura, função e aspectos sociais. FUNDIBIO, Botucatu, pp.653-685.

Huszar, V.L.M., Silva, L.H.S., Marinho, M.M., Domingos, P. \& Sant'Anna, C.L. 2000. Cyanoprokaryote assemblages in eight productive tropical Brazilian waters. In: C.S. Reynolds, M. Dokulil \& J. Padisák (eds.). The Trophic Spectrum Revisited: The Influence of Trophic State on the Assembly of Phytoplankton Communities Kluwer. Academic Publishers, Dordrecht, pp. 67-77.

Kitamura, P.C., Lopes, R.B., Castro Jr. \& Queiroz, J.F. 1999. Avaliação Ambiental e Econômica dos Pesqueiros Esportiva na Bacia do Rio Piracicaba. Boletim da Indústria Animal 56: 95-107.

Komárek, J. 1983. Contribution to the chlorococcal algae of Cuba. Nova Hedwigia 37: 65-180.

Komárek, J., \& Fott, B. 1983. Das Phytoplankton des Susswassers. Systematik und Biologie. Chlorophyceae (Grünalgen) Ordenung: Chlorococcales. E. Schweizerbart'sche verlagsbuchhandlung, Stuttgart.

Komárek, J. \& Marvan, P. 1992. Morphological diferences in natural populations of the genus Botryococcus (Chlorophyceae). Archiv Protistenk 141: 65-100.

Komárková-Legnerová, J. 1969. The systematics and ontogenesis of the genera Ankistrodesmus Corda and Monoraphidium gen. nov. In: B. Fott (ed.), Studies in Phycology. E. Schweizerbartsche Verlagsbuchhandlung, Sttutgart, pp.75-144.

Korshikov, O.A. 1953. Pidklas protokokovi (Subclasse Protococcineae): Vakuol'ni (Vacuolales) ta Protokokovi (Protococcales). Vyznacnik Prisnovodnich Vodorosley Ukraiynskoy SSR (The freshwater algae of the Ukrainian SSR). Akademiya Nauka Ukraiynskoy SSR.

Lopes, R.B. 2000. Caracterização dos lagos de pesca esportiva frente à qualidade de água e ao manejo empregado. Dissertação de Mestrado, Universidade Estadual Paulista, Ilha Solteira.

Luo, W., Pflugmacher, S., Pröschold, T., Walz, N. \& Krienitz, L. 2006. Genotype versus Phenotype Variability in Chlorella and Micractinium (Chlorophyta, Trebouxiophyceae). Protist 157: 315-333.

Matsuzaki, M., Mucci, J.L.N. \& Rocha, A.A. 2004. Comunidade fitoplanctônica de um pesqueiro na cidade de São Paulo. Revista de Saúde Pública 38: 679-686.

Mercante, C.T.J., Cabianca, M.A., Silva, D. Costa, S.V. \& Esteves, K.E. 2004. Water quality in free-fishing ponds located in the metropolitan region of São Paulo city, Brazil: an analysis of the eutrophication process. Acta Limnologica Brasiliensia 16: 95-102. 
Mercante, C.T.J., Costa, S.V., Silva, D., Cabianca, M.A.A. \& Esteves, K.E. 2005. Qualidade da água em pesque-pague da região metropolitana de São Paulo (Brasil): avaliação através de fatores abióticos (período seco e chuvoso). Acta Scientiarum Biological Sciences 27: 1-7.

Mercante, C.T.J., Silva, D. \& Costa, S.V. 2006. Avaliação da qualidade da água de pesqueiros da região metroplitana de São Paulo por meio do uso de variáveis abióticas e clorofila. In: K.E. Esteves \& C.L. Sant'Anna (org.). Pesqueiros sob uma visão integrada de meio ambiente saúde pública e manejo. Rima, São Paulo, pp. 37-48.

Mercante, C.T.J., Martins, Y.K., Carmo, C.F., Osti, J.S., Pinto, C.S.R. \& Tucci, A. 2007. Qualidade da água em viveiro de tilápia do Nilo (Oreochromis niloticus): caracterização diurna de variáveis físicas, químicas e biológicas, São Paulo, Brasil. Bioikos 21: 79-88.

Nogueira, I.S. 1991. Chlorococcales sensu lato (Chlorophyceae) do município do Rio de Janeiro e arredores, Brasil: inventário e considerações taxonômicas. Dissertação de Mestrado, Universidade Federal do Rio de Janeiro, Rio de Janeiro.

Nogueira, I.S. 1999. Estrutura e dinâmica da comunidade fitoplanctônica da Represa Samambaia, Goiás, Brasil. Tese de Doutorado, Universidade de São Paulo. São Paulo.

Nogueira, I.S., Nabout, C.J., Oliveira, J.E. \& Silva, K.D. 2008. Diversidade (alfa, beta e gama) da comunidade fitoplanctônica de quatro lagos artificiais urbanos do município de Goiânia, GO. Hoehnea 35: 219-233.

Philipose, M.T. 1967: Chlorococcales. Indian Council of Agricultural Research Monographs, NewDelhi.

Rehakova, H. 1969. Die variabilitat der Aten der Gattung Oocystis A. Braun. In: B. Fott (ed.). Studies in Phycology. E. Schweizerbart'sche Verlagsbuchhandlung, Sttutgart, pp. 145-196.

Rodrigues, L.L. 2008. Biodiversidade de Cianobactérias e Algas das Represas Billings (Braço Taquacetuba) e Guarapiranga, SP, Brasil. Dissertação de Mestrado, Universidade de São Paulo, São Paulo.

Rosini, E.F. 2010. Fitoplâncton de Pesqueiros da Região Metropolitana de São Paulo: Levantamento Florístico. Dissertação de Mestrado, Instituto de Botânica, São Paulo.

Sant'Anna, C.L. 1984. Chlorococcales (Chlorophyceae) do Estado de São Paulo, Brasil. Bibliotheca Phycologica 67: 1-348.
Sant'Anna, C.L., Azevedo, M.T.P. \& Sormus, L. 1989. Fitoplâncton do Lago das Garças, Parque Estadual das Fontes do Ipiranga, São Paulo, SP, Brasil: Estudo Taxonômico e Aspectos Ecológicos. Hoehnea 16: 89-131.

Sant'Anna, C.L., Sormus, L., Tucci, A. \& Azevedo, M.T.P. 1997. Variação sazonal do fitoplâncton do Lago das Garças, São Paulo, SP. Hoehnea 24: 67-86.

Sant'Anna, C.L., Gentil, R.C. \& Silva, D. 2006. Comunidade fitoplanctônica de pesqueiros da região metropolitana de São Paulo. In: K.E. Esteves \& C.L. Sant'Anna (org.). Pesqueiros sob uma visão integrada de meio ambiente saúde pública e manejo. Rima, São Paulo, pp. 49-62.

Senna, P.A.C. \& Magrin, A.G.E. 1999. A importância da "boa" identificação dos organismos fitoplanctônicos para os estudos ecológicos. In: L.M.M. Pompêo (ed.). Perspectiva da Limnologia no Brasil. Gráfica e Editora União, São Luis, pp.131-146.

Silva, D. 2005. Dinâmica de populações de Microcystis (Cyanobacteria) em pesqueiros da Região Metropolitana de São Paulo, SP, Brasil. Dissertação de Mestrado. Instituto de Botânica, São Paulo.

Sodomková, M. 1972. Taxonomische Übersicht der Gttung Coelastrum Nageli. Acta Universitatis CarolinaeBiologica 1970: 481-512.

Tell, G. 2001. The species of the genus Coelastrum Nageli (Chlorophyceae, Chlorococcales) from Argentina and its geographical distribution. Algological Studies 102: 61-71.

Treviño, I.F. 2008. Estúdios taxonômicos en algas coccales del sur de Espanã. Tesis Doctoral, Universidad de Granada Facultad de Ciênicas Departamento de Botânica, Granada.

Tucci, A., Deberdt, A.J. \& Deberdt, G.L.B. 2004. Análise da comunidade fitoplanctônica do reservatório de Salto Grande (Americana, SP): Uma revisão dos estudos desenvolvidos em um sistema eutrófico. In: E.L.G. Espindola, M.A. Leite \& C.B. Dornfeld (orgs.). Reservatório de Salto Grande (Americana, SP): Caracterização, impactos e propostas de manejo. Rima, São Carlos, pp.107-153.

Tucci, A., Sant'Anna, C.L., Gentil, R.C. \& Azevedo, M.T.P. 2006. Fitoplâncton do Lago das Garças, São Paulo, Brasil: um reservatório urbano eutrófico. Hoehnea 33: 147-175. 